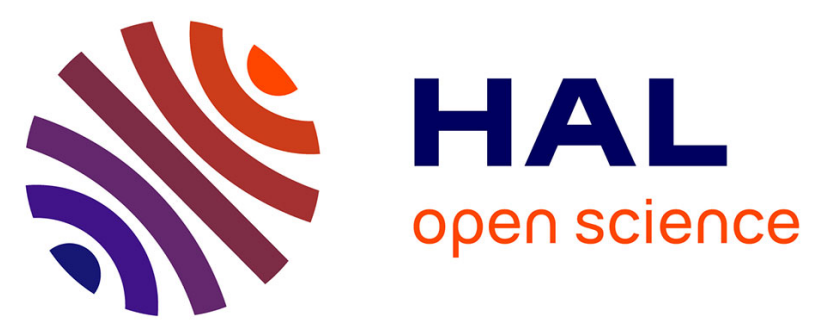

\title{
Americium recovery from highly active PUREX raffinate by solvent extraction: the EXam process. a review of 10 years of $R \& D$
}

Manuel Miguirditchian, Vincent Vanel, Cécile Marie, Vincent Pacary, Marie-Christine Charbonnel, Laurence Berthon, Xavier Hérès, Marc Montuir, Christian Sorel, Marie-Jordane Bollesteros, et al.

\section{To cite this version:}

Manuel Miguirditchian, Vincent Vanel, Cécile Marie, Vincent Pacary, Marie-Christine Charbonnel, et al.. Americium recovery from highly active PUREX raffinate by solvent extraction: the EXam process. a review of 10 years of R\&D. Solvent Extraction and Ion Exchange, 2020, 38 (4), pp.365-387. 10.1080/07366299.2020.1753922 . cea-03541148

\section{HAL Id: cea-03541148 \\ https: / hal-cea.archives-ouvertes.fr/cea-03541148}

Submitted on 24 Jan 2022

HAL is a multi-disciplinary open access archive for the deposit and dissemination of scientific research documents, whether they are published or not. The documents may come from teaching and research institutions in France or abroad, or from public or private research centers.
L'archive ouverte pluridisciplinaire HAL, est destinée au dépôt et à la diffusion de documents scientifiques de niveau recherche, publiés ou non, émanant des établissements d'enseignement et de recherche français ou étrangers, des laboratoires publics ou privés. 


\section{Americium Recovery from Highly Active PUREX Raffinate by Solvent Extraction: The EXAm Process. A Review of 10 Years of R\&D}

Manuel Miguirditchian, Vincent Vanel, Cécile Marie, Vincent Pacary, MarieChristine Charbonnel, Laurence Berthon, Xavier Hérès, Marc Montuir, Christian Sorel, Marie-Jordane Bollesteros, Sylvain Costenoble, Christine Rostaing, Michel Masson \& Christophe Poinssot

To cite this article: Manuel Miguirditchian, Vincent Vanel, Cécile Marie, Vincent Pacary, MarieChristine Charbonnel, Laurence Berthon, Xavier Hérès, Marc Montuir, Christian Sorel, MarieJordane Bollesteros, Sylvain Costenoble, Christine Rostaing, Michel Masson \& Christophe Poinssot (2020): Americium Recovery from Highly Active PUREX Raffinate by Solvent Extraction: The EXAm Process. A Review of 10 Years of R\&D, Solvent Extraction and Ion Exchange

To link to this article: https://doi.org/10.1080/07366299.2020.1753922

$$
\text { 曲 Published online: } 27 \text { Apr } 2020 .
$$

Submit your article to this journal 지

View related articles

View Crossmark data $\circlearrowright$ 


\title{
Americium Recovery from Highly Active PUREX Raffinate by Solvent Extraction: The EXAm Process. A Review of 10 Years of R\&D
}

\author{
Manuel Miguirditchian (D), Vincent Vanel (D), Cécile Marie (D), Vincent Pacary, \\ Marie-Christine Charbonnel, Laurence Berthon, Xavier Hérès, Marc Montuir, Christian Sorel, \\ Marie-Jordane Bollesteros, Sylvain Costenoble, Christine Rostaing, Michel Masson, \\ and Christophe Poinssot
}

CEA, DES, ISEC, DMRC, University Montpellier, Marcoule, France

\begin{abstract}
In the framework of the R\&D program conducted in France on partitioning and transmutation of minor actinides, a solvent extraction process was developed for separating americium from a PUREX raffinate arising from the dissolution of spent nuclear fuels in nitric acid. The so-called EXAm process uses a mixture of a malonamide (DMDOHEMA, $N, N^{\prime}$-dimethyl- $N, N^{\prime}$-dioctyl-hexyloxyethylmalonamide) and HDEHP (di-2-ethylhexylphosphoric acid) in organic phase in combination with a water-soluble complexing agent TEDGA $\left(N, N, N^{\prime}, N^{\prime}-\right.$ tetraethyldiglycolamide) in aqueous phase to enhance $\mathrm{Am} / \mathrm{Cm}$ separation. $\mathrm{Am} /$ Ln separation is then obtained by selective Am stripping with polyaminocarboxylic acids (HEDTA or DTPA) buffered by citric or malonic acid at low acidity. Started in 2008, an important R\&D program was conducted at CEA to optimize and model the process. The feasibility of the direct recovery of Am from a genuine PUREX raffinate by solvent extraction was demonstrated in 2010 and reported, for the first time in the literature. R\&D was then conducted to adapt the process for a future scale-up and for application from concentrated PUREX raffinates. The results of the final EXAm process performed on a highly active PUREX concentrate are presented after a summary of 10 years of R\&D on this process development.
\end{abstract}

\section{KEYWORDS}

Spent nuclear fuel reprocessing; americium separation; EXAm process; solvent extraction; highly active concentrate; TEDGA

\section{Introduction}

Spent nuclear fuels are, in France, currently reprocessed in the la Hague plant by using the PUREX process (Plutonium Uranium Reduction Extraction). ${ }^{[1]}$ Uranium and plutonium are separated from fission products (FP) and minor actinides (MA, neptunium, americium, and curium) by solvent extraction with TBP (tri- $n$-butyl phosphate) and the recovered plutonium is mono-recycled in LWR MOX fuel. This reprocessing allows not only saving of uranium natural resources but also a significant reduction of the volume and radiotoxicity of high-level nuclear waste (HLW) ${ }^{[2]}$ since plutonium is the main contributor to the long-term radiotoxicity of spent nuclear fuels. The fission products and minor actinides recovered in the PUREX raffinate are then vitrified to produce nuclear glasses, considered as the ultimate nuclear waste for HLW. After about 100 years of cooling, americium and curium become the main contributors to the radiotoxicity and to residual heat power of ultimate nuclear waste (Figure 1). The heat load is the key factor for designing the deep geological repository. Indeed, the distance between HLW canisters needs to be large enough to limit the temperature increase of the geological medium. Therefore, the recovery of the minor actinides from PUREX raffinates for further transmutation in Generation IV fast reactors (the so-called P\&T 


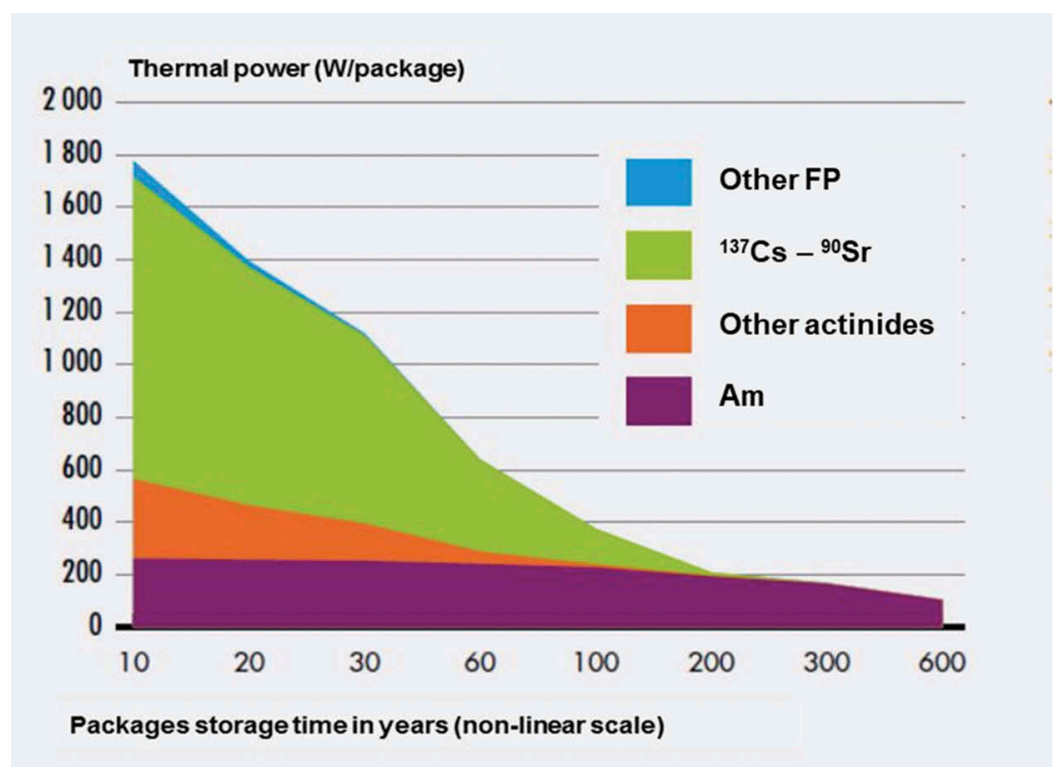

Figure 1. Residual thermal power of ultimate nuclear wastes after reprocessing of UOX spent fuel.

strategy), coupled with a sufficient storage period of the remaining HLW allowing the heat loading generated by radionuclides of lower lifetime to decrease, could allow a reduction in the footprint of a deep geological repository site. A study conducted by CEA jointly with the French National Agency for Radioactive Waste Management (ANDRA) shows that a factor up to 7 could be gained on the HLW surface area in the event of clay concept repository. ${ }^{[3]}$

In this context, a French legislative Act opened on December 30, 1991 required the exploration of different options for partitioning and transmutation of long-lived radionuclides. Within this framework, CEA has developed, during more than 20 years, minor actinide partitioning processes at laboratory scale on samples of actual spent fuels. Given the high acidity $\left(\mathrm{HNO}_{3} 3\right.$ to 4 mol. $\left.\mathrm{L}^{-1}\right)$ and the multi-elementary composition of a PUREX raffinate (30 times more fission products, including lanthanides ( $\mathrm{Ln})$, than minor actinides), the first strategy adopted initially in the 90s was a selective and stepwise extraction of actinides(III) (An(III)) (Figure 2). First, An(III) and Ln(III) were coextracted by a bidentate O-donor malonamide extractant (DIAMEX process) ${ }^{[4-10]}$ Then, An(III) were separated from $\mathrm{Ln}(\mathrm{III})$ in a less acidic mixture using soft $\mathrm{N}$-donor ligands (SANEX process) ${ }^{[11-14]}$ before Am/Cm separation using either the SESAME process (oxidation and extraction of Am(VI) by tri- $n$-butyl phosphate $)^{[15]}$ or an alternative of the DIAMEX process $\left(\mathrm{Am}^{3+} / \mathrm{Cm}^{3+}\right.$ separation with the malonamide DMDOHEMA). ${ }^{[16]}$ Many extraction systems were tested. Some of them were developed up to hot cell demonstration on genuine solutions, sometimes in the frame of European projects ${ }^{[17-}$ ${ }^{24]}$ Advances in Europe on the development of minor actinide separation processes have been recently reported. ${ }^{[25]}$ In 2005, the feasibility of the minor actinide partitioning was demonstrated on several kilograms of actual spent fuel in ATALANTE facility. ${ }^{[26,27]}$

Since June 2006, with the second French Act on nuclear waste management, the strategy of the CEA has been focused on a process simplification approach and specifically on the partitioning and transmutation of only americium. Am separation would provide the greatest benefits on the waste management and present the most moderate impacts on the implementation of the recycling operations. Indeed, recycling $\mathrm{Cm}$ has been anticipated to be difficult to implement due to the significant neutron emissions of $\mathrm{Cm}$ which would require very thick shielding at any step of the fuel cycle. Recycling Am is thus a good compromise between limiting the $\mathrm{Cm}$ recycling issues and saving the repository resource for future generations. The goal is to directly extract and separate 


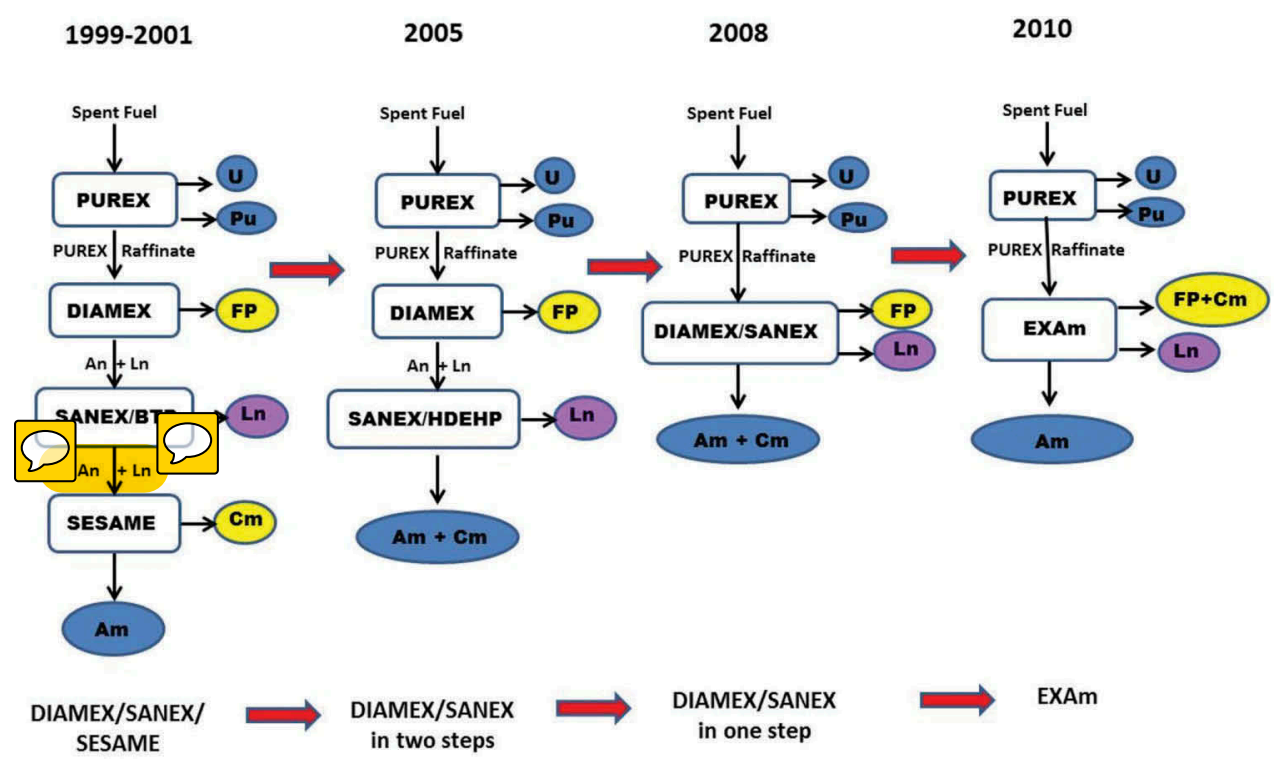

Figure 2. MA partitioning routes developed at the CEA from 1999 to 2010.

Am(III) from the PUREX raffinate in one single step instead of the three successive SX cycles (DIAMEX, SANEX, and Am/Cm separation) (Figure 2). The main challenge to overcome is to separate $\mathrm{Am}$ (III) from $\mathrm{Cm}$ (III) and $\mathrm{Ln}$ (III) from concentrated nitric acid solution in spite of their very close size and physico-chemical properties. Based on the knowledge gained over the past 20 years on MA partitioning, a single-cycle process, called EXAm (for Extraction of Americium) was thus developed to reach this objective.

This paper is a review of the R\&D performed in France on this process since 2008. It presents the principle of the EXAm process and reports the main results obtained from batch distribution experiments, speciation and modelling studies as well as hot pilot tests performed on genuine PUREX high active raffinate (HAR). It is also an example to illustrate the classical methodology used by the CEA to develop a process from lab-scale batch experiments up to a potential industrial application strongly supported by modeling and simulation studies.

\section{Principle of the EXAm process}

The general flowsheet of the EXAm process is depicted in Figure 3. Americium is first extracted by an organic solvent made of a mixture of HDEHP (di-2-ethylhexylphosphoric acid) and DMDOHEMA ( $N, N^{\prime}$-dimethyl- $N, N^{\prime}$-dioctyl-hexyloxyethyl-malonamide) diluted in TPH (hydrogenated tetrapropylene) (Figure 4). A water soluble complexing agent, TEDGA ( $N, N, N$, $N^{\prime}$-tetraethyldiglycolamide), ${ }^{[28]}$ is added into the feed solution and in the scrubbing solution to improve the $\mathrm{Am} / \mathrm{Cm}$ selectivity and thus, to reduce the number of theoretical separation stages

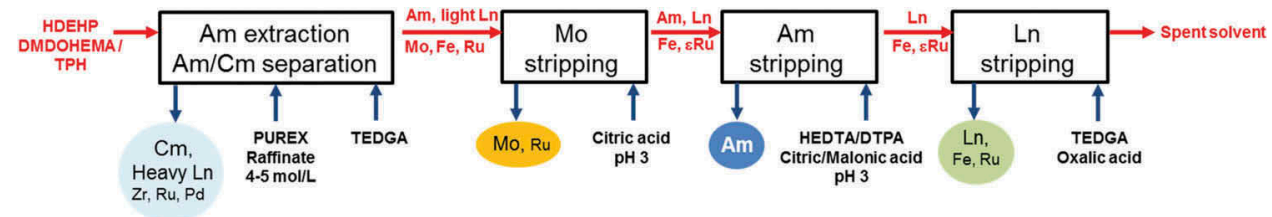

Figure 3. General flowsheet of the EXAm process. 


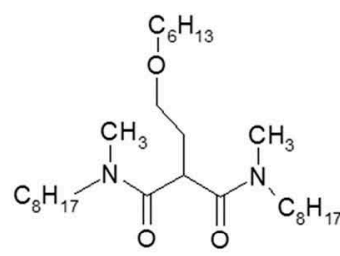

DMDOHEMA $N, N$ 'dimethyl- $N, N$ '-dioctylhexyloxyethyl-malonamide<smiles>O=C(O)CN(CCO)CCN(CC(=O)O)CC(=O)O</smiles>

HEDTA $\mathrm{N}$-(2-hydroxyethyl)ethylenediamine$\mathrm{N}, \mathrm{N}^{\prime}, \mathrm{N}^{\prime}$-triacetic acid<smiles>CCCCC(CC)COP(=O)(O)OCC(CC)CCCC</smiles>

HDEHP Di-2-ethylhexylphosphoric acid<smiles>CCN(CC)C(=O)COCC(=O)N(CC)CC</smiles>

TEDGA

$N, N, N^{\prime}, N$ 'tetra-ethyldiglycolamide<smiles>O=C(O)CC(O)(CC(=O)O)C(=O)O</smiles>

Citric acid<smiles>O=C(O)CN(CCN(CC(=O)O)CC(=O)O)CCN(CC(=O)O)CC(=O)O</smiles>

DTPA Diethylenetriaminepentaacetic acid<smiles>O=C(O)CC(=O)O</smiles>

Malonic acid

Figure 4. Chemical structures of the molecules used in the EXAm process: DMDOHEMA, HDEHP, TEDGA, HEDTA, citric acid, DTPA, and malonic acid.

required for Am/Cm separation. Light lanthanides, as well as some fission and corrosion products like $\mathrm{Mo}, \mathrm{Ru}, \mathrm{Pd}, \mathrm{Fe}$ are also extracted in the organic phase along with Am while curium and heavy lanthanides remain in the aqueous phase. As some fission/corrosion products would be backextracted with Am, specific scrubbing steps are required to remove these elements prior or after the stripping of Am. As molybdenum is complexed by DTPA, it is necessary to remove it prior to the Am stripping step in order to avoid any Am loss. A specific step was thus implemented to selectively back-extract molybdenum from the solvent with citric acid in diluted nitric acid. Then, Am can be selectively stripped by a polyaminocarboxylic acid, HEDTA ( $N$-(2-hydroxyethyl)ethylenediamine- $N, N^{\prime}, N^{\prime}$-triacetic acid) or DTPA (diethylenetriaminepentaacetic acid) in a mixture with a $\mathrm{pH}$-buffer (citric or malonic acid) at $\mathrm{pH} \mathrm{2-3}$ and separated from light lanthanides which remain extracted in the organic phase by HDEHP. Light lanthanides and iron are eventually stripped from the organic phase using complexing agents to allow solvent recycling after specific acidic and basic scrubbings. The purified americium could then be converted to americium oxide by oxalic precipitation and calcination in order to fabricate $\mathrm{UAmO}_{2}$ specific pellets for future transmutation through Am-bearing blankets in fast neutron reactors. ${ }^{[29,30]}$

\section{Batch distribution and speciation studies for a non-concentrated $x$ raffinate}

\section{Impact of TEDGA on MA and Ln extraction}

The EXAm solvent (HDEHP 0.3 mol. $\mathrm{L}^{-1}+$ DMDOHEMA 0.6 mol. $\mathrm{L}^{-1}$ in TPH) exhibits a low selectivity for Am versus $\mathrm{Cm}\left(\mathrm{SF}_{\mathrm{Am} / \mathrm{Cm}}=1.6\right)$ which would imply a very high number of extraction and scrubbing stages to recover quantitatively pure Am. To reduce this number of stages and improve the process compactness, TEDGA was added into the feed solution to enhance the Am/ Cm selectivity. ${ }^{[31]}$ Among the different water-soluble diglycolamide compounds tested, TEDGA seems to have the optimal amidic symmetrical chain length (2 carbons) to ensure optimized Am/ Cm separation ${ }^{[32-.34]}$ 


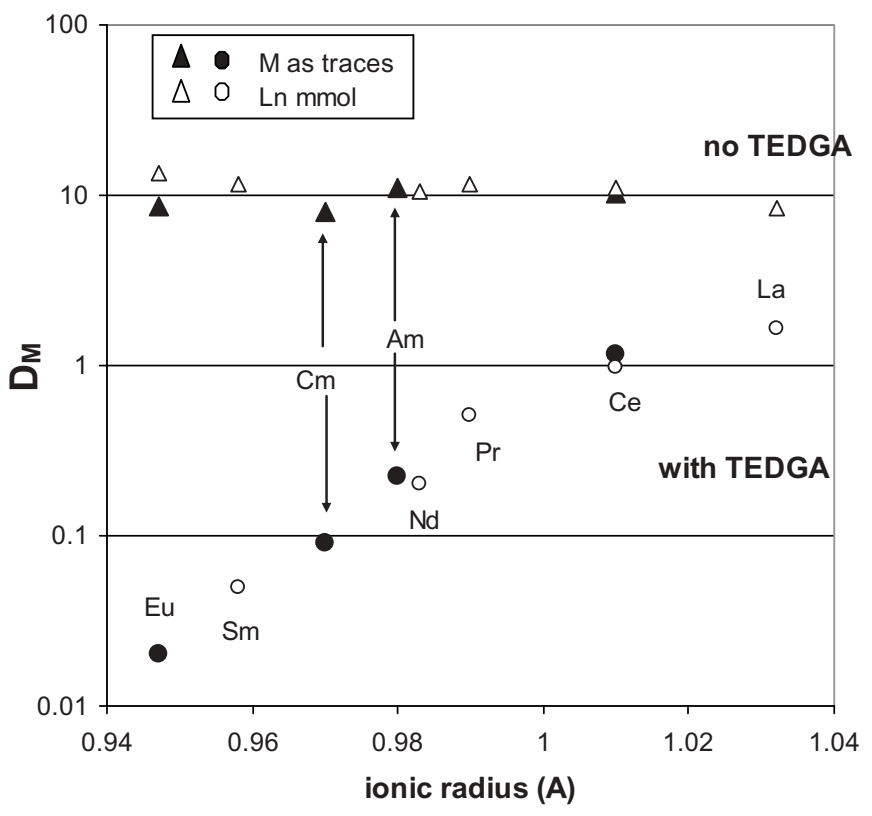

Figure 5. Distribution ratios of $\operatorname{Ln}(\mathrm{III})$ and An(III) with and without TEDGA (DMDOHEMA 0.6 mol. $\mathrm{L}^{-1}, \mathrm{HDEHP} 0.3 \mathrm{~mol} . \mathrm{L}^{-1}$ in TPH $[\mathrm{TEDGA}]=0$ or $0.05 \mathrm{~mol} . \mathrm{L}^{-1}$ in $\left.\mathrm{HNO}_{3} 5 \mathrm{~mol} . \mathrm{L}^{-1}, 25^{\circ} \mathrm{C}\right)$.

The distribution ratios of $\mathrm{Am}, \mathrm{Cm}$, and lanthanides with and without TEDGA are reported in Figure 5 as a function of their ionic radius after extraction by the EXAm solvent. The combination of DMDOHEMA in organic phase and TEDGA in aqueous phase allows an increase of the Am/Cm separation factor from 1.6 to 2.5 but also drastically enhances the selectivity between light (La-Nd) and heavy lanthanides (Sm-Gd). Lanthanide extraction regularly decreases with $\mathrm{Z}$ along the series due to a stronger complexation by TEDGA when the ionic radius decreases. This trend follows the classical law for ionic-type interactions generally observed between $\mathrm{O}$-donor ligands and $f$-element cations. Americium behavior is very close to neodymium, while curium behavior is somewhere between $\mathrm{Nd}$ and Sm. Yttrium behaves like a heavy lanthanide and would be mainly maintained in the aqueous phase with curium.

As TEDGA was shown to be co-extracted with $\mathrm{Ln}^{3+}$ and $\mathrm{An}^{3+}$ cations in the organic phase, ${ }^{[35]}$ speciation studies have been performed in both phases to understand the main mechanisms occurring in the EXAm process. Lanthanide(III) and americium(III)-TEDGA complexes were first characterized in aqueous medium by different experimental techniques (ESI-MS, TRLIFS, UV-vis spectrophotometry, and microcalorimetry) supported by molecular dynamics calculations. ${ }^{[36]}$ It appears clearly from these results that 1:1 LnTEDGA ${ }^{3+}$ and 1:2 LnTEDGA $_{2}{ }^{3+}$ complexes would be favored with light lanthanides ( $\mathrm{La}, \mathrm{Pr}$ ) whereas only 1:3 LnTEDGA $_{3}{ }^{3+}$ would be predominant in aqueous phase with the heavier lanthanides (Dy). On the other hand, both 1:1, 1:2, and 1:3 M$\mathrm{TEDGA}_{\mathrm{n}}{ }^{3+}$ complexes would co-exist for middle-series $\mathrm{Ln}(\mathrm{Eu})$ and $\mathrm{Am}^{3+}$ (Table 1). As observed from distribution experiments (Figure 5), the complexation strength between Ln cations and TEDGA increases with the atomic number through the series as already reported previously. ${ }^{[36]}$

Table 1. Stability constants determined for $\mathrm{Ln}$ and Am-TEDGA complexes in $\mathrm{NaNO}_{3} 1$ mol.L $\mathrm{L}^{-1}, \mathrm{pH}$ $2,25^{\circ} \mathrm{C}$ by UV-vis spectrophotometry (a) or microcalorimetry $(b)^{[36]}$.

\begin{tabular}{lccc}
\hline Metal & $\log \beta_{1}$ MTEDGA $^{3+}$ & $\log \beta_{2}$ MTEDGA $_{2}{ }^{3+}$ & $\log \beta_{3}$ MTEDGA $_{3}{ }^{3+}$ \\
\hline $\mathrm{Pr}$ & $2.0 \pm 0.1^{\mathrm{a}}$ & $3.5 \pm 0.1^{\mathrm{a}}$ & \\
$\mathrm{Yb}$ & - & - & $9.2 \pm 0.1^{\mathrm{b}}$ \\
$\mathrm{Am}$ & $2.9 \pm 0.1^{\mathrm{a}}$ & $6.1 \pm 0.1^{\mathrm{a}}$ & $8.3 \pm 0.1^{\mathrm{a}}$ \\
\hline
\end{tabular}


Dedicated extraction experiments and complexation studies directly in the solvent were then performed to understand the behavior and impact of TEDGA in the DMDOHEMA-HDEHP extracting system. Indeed, although TEDGA is a hydrophilic ligand, its partial transfer to the solvent during the extraction process must be taken into account. Without cations, TEDGA is scarcely extracted by the EXAm solvent $(\mathrm{D} \leq 0.1)$ but TEDGA distribution slightly increases with the nitric acid concentration. This trend was explained by TEDGA co-extraction with $\mathrm{HNO}_{3}$ and DMDOHEMA, potentially as an adduct formed between protonated TEDGA and DMDOHEMA [DMDOHEMA-TEDGA- $\left.\mathrm{H}^{+}, \mathrm{NO}_{3}{ }^{-}\right] \cdot{ }^{[35]}$ In the presence of lanthanides (or actinides), the partition of TEDGA in the organic phase is enhanced $(0.1<\mathrm{D}<0.2)$ and depends on the metal concentration loaded in organic phase and on the lanthanide atomic number (Figure 6). For light lanthanides (La for example), the concentration of TEDGA extracted into the organic phase increases regularly with the organic cation concentration while TEDGA organic concentration first decreases before increasing in the case of heavier lanthanides ( $\mathrm{Sm}$ and $\mathrm{Eu}$, for example). Different lanthanide complexes involving potentially several molecules of TEDGA would be co-extracted by DMDOHEMA and HDEHP in the organic phase and their formation was confirmed by ESI-MS experiments. Ternary and quaternary complexes involving 1 or 2 molecules of TEDGA were detected in the organic phase with the following general formula: $\operatorname{Ln}(\text { TEDGA })_{\mathrm{n}}(\mathrm{DMDOHEMA})_{\mathrm{x}}(\mathrm{DEHP})_{\mathrm{y}}\left(\mathrm{NO}_{3}\right)_{3-\mathrm{y}}$ (with $\mathrm{n}=1$ or $2, \mathrm{x}=1$ or $2, \mathrm{y}=1$ or 2) (Figure 7). 1:3 Ln-TEDGA complexes favored with heavier lanthanides were not observed in the organic phase and would thus remain in the aqueous phase, explaining the masking effect of TEDGA on heavy lanthanides extraction.

It was therefore assumed from these results that the different proportion of 1:1, 1:2, and 1:3 $\mathrm{An}(\mathrm{TEDGA})_{\mathrm{n}}$ complexes observed between $\mathrm{Am}$ and $\mathrm{Cm}$ and more precisely, the ratio of $1: 1$ and 1:2 An(TEDGA $)_{1,2}(\mathrm{DMDOHEMA})_{\mathrm{x}}(\mathrm{DEHP})_{\mathrm{y}}\left(\mathrm{NO}_{3}\right)_{3-\mathrm{y}}$ mixed complexes formed in the solvent, is a key parameter to explain the enhancement of Am/Cm selectivity with TEDGA. ${ }^{[34]}$ Partitioning of TEDGA complicates the process and its modelling but appears as an essential factor for enhancing Am/Cm selectivity. The lower partitioning observed with other water-soluble DGA compounds such as TMDGA and TnPDGA would contribute to explain the lower Am/Cm separation factor measured with these molecules compared to TEDGA in the same experimental conditions. $^{[32]}$

According to the speciation studies, the different complexation and extraction equilibria occurring in the aqueous phase and between both phases in presence of TEDGA in the EXAm process conditions are depicted in Figure 8. The phenomenological model based on these equilibria is further detailed in the modelling discussion.

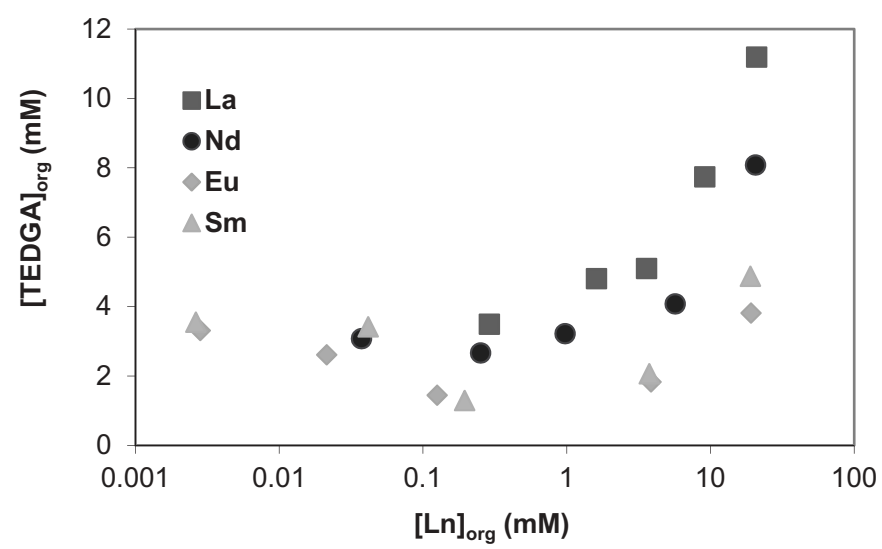

Figure 6. Concentration of TEDGA extracted in the organic phase as a function of the concentration of lanthanide cations in the organic phase (DMDOHEMA $0.6 \mathrm{~mol} . \mathrm{L}^{-1}$-HDEHP $0.3 \mathrm{~mol} . \mathrm{L}^{-1}$ in TPH, $\left[\right.$ TEDGA] $=0.05 \mathrm{~mol} . \mathrm{L}^{-1},\left[\mathrm{HNO}_{3}\right]=4 \mathrm{~mol} . \mathrm{L}^{-1}, 25^{\circ} \mathrm{C}$ ). 


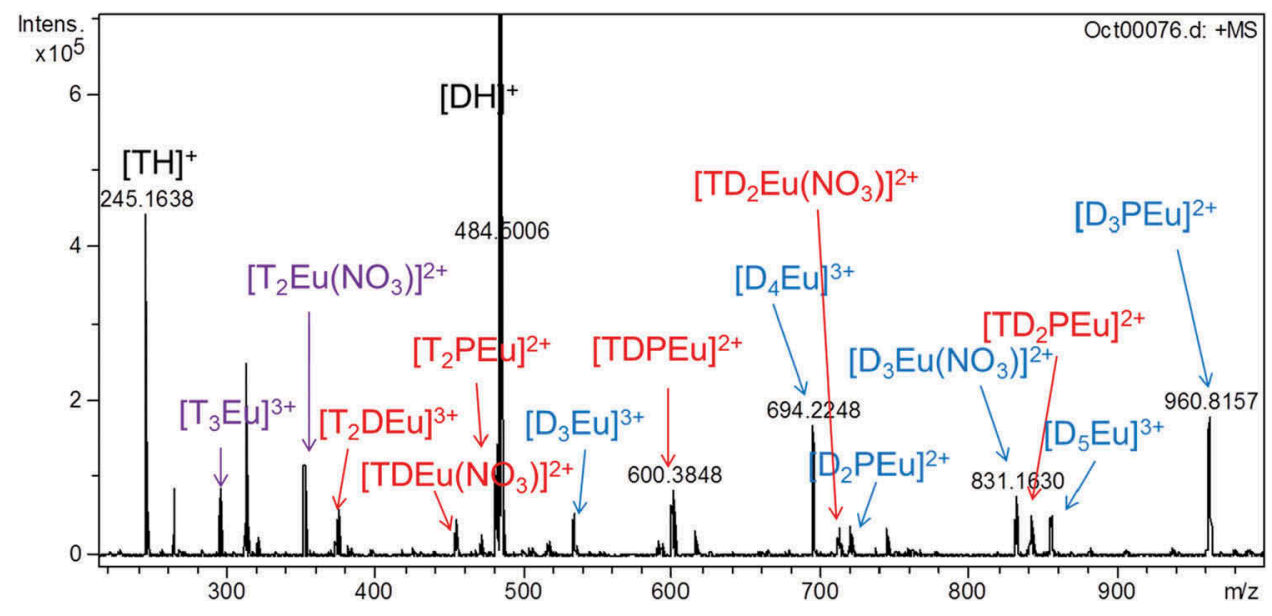

Figure 7. ESI-MS spectrum of DMDOHEMA $3.10^{-3}$ mol.L ${ }^{-1}$, HDEHP $1.5 .10^{-3} \mathrm{~mol} . \mathrm{L}^{-1}$, TEDGA $1.5 .10^{-3} \mathrm{~mol} . \mathrm{L}^{-1}$, Eu $1.5 .10^{-3} \mathrm{~mol} . \mathrm{L}^{-1}$ and $\mathrm{HNO}_{3} 3.10^{-3}$ mol. $\mathrm{L}^{-1}$ diluted ten times in acetonitrile/water $(50-50 \%$ vol.), positive ionization mode, (D = DMDOHEMA, $\mathrm{HP}=\mathrm{HDEHP}, \mathrm{T}=\mathrm{TEDGA})$.

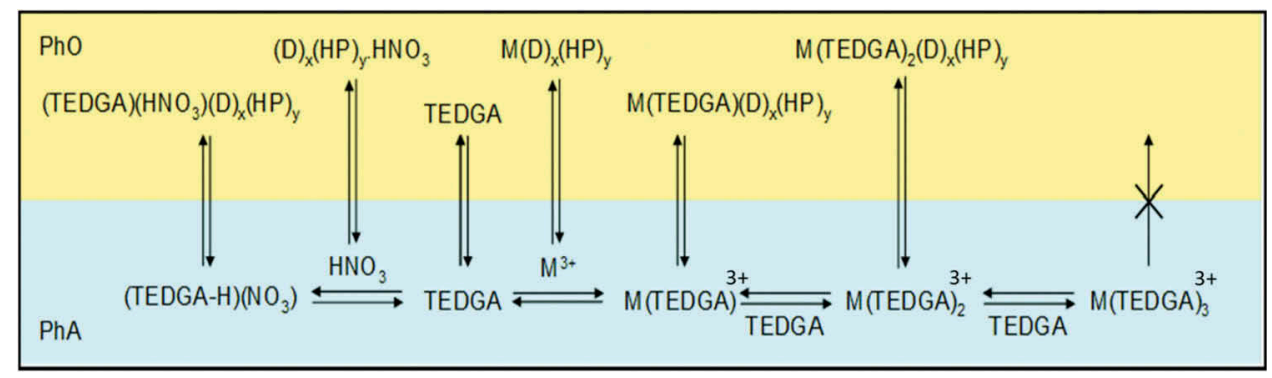

Figure 8. Schematic view of complexation equilibria and extraction mechanisms involving TEDGA in the biphasic system DMDOHEMA (D), HDEHP (HP)/HNO 3 , TEDGA, Ln/An (M).

\section{Behavior of problematic fission and corrosion products (Mo, $\mathrm{Zr}, \mathrm{Ru}, \mathrm{Pd}, \mathrm{Fe}$ )}

Extraction of palladium, ruthenium, iron, molybdenum, and zirconium was studied with the EXAm solvent. The knowledge of their interactions with both extractants and TEDGA is very important since it could decrease the concentration of free ligand available to perform the Am/Cm separation and will determine, if required, the conditions of their further stripping to avoid any contamination of the americium product.

Similarly, as heavy lanthanides (III) and zirconium (IV) are strongly complexed by TEDGA in the aqueous phase and forms stable 1:3 Zr-TEDGA complexes. As a result, extraction of $\mathrm{Zr}$ in the organic phase is totally prevented in presence of an excess of TEDGA. However, due to relatively slow complexation kinetics, TEDGA must be directly added in the feed solution as a masking agent before $\mathrm{Zr}$ extraction by the EXAm solvent.

Iron (III) and molybdenum (VI) are extracted by HDEHP and DMDOHEMA even in the presence of TEDGA $\left(\mathrm{D}_{\mathrm{Mo}}, \mathrm{Fe}, 30\right)$ and they follow americium in the organic phase. Conditions were not found to mask iron extraction or to scrub it before the Am stripping step. Iron is then back-extracted using oxalic acid in the last step of the process along with light lanthanides stripped by TEDGA in $\mathrm{HNO}_{3} 1 \mathrm{~mol} . \mathrm{L}^{-1}$ (Figure 3).

At high acidity $\left(\left[\mathrm{HNO}_{3}\right]>1 \mathrm{~mol} . \mathrm{L}^{-1}\right)$, molybdenum, present as $\mathrm{MoO}_{2}{ }^{2+[37]}$ is strongly extracted by the EXAm solvent according to a solvation mechanism. Two dimers of HDEHP would be 
involved in the complex with potential participation of DMDOHEMA. ${ }^{[38]}$ At lower acidity $(\mathrm{pH}>2)$, formation of neutral or anionic species $\left(\mathrm{MoO}_{3}, \mathrm{MoO}_{4}{ }^{2-}\right)$ is also assumed in aqueous phase and have to be taken into account to model Mo extraction on the whole $\mathrm{pH}$ range. ${ }^{[38]} \mathrm{A}$ dedicated scrubbing was implemented, after the $\mathrm{Am} / \mathrm{Cm}$ separation step, to back-extract Mo from the solvent. Mo stripping can be achieved at low acidity ( $\mathrm{pH} 2-3$ ) with minimal losses of americium by using ahydroxy-carboxylic acids (citric or glycolic acid) acting as $\mathrm{pH}$ buffer and as complexing agent for molybdenum. A 0.5 mol. $\mathrm{L}^{-1}$ citric acid solution at $\mathrm{pH} 3$ was selected after batch experiments to quantitatively strip Mo in the EXAm flowsheet.

Palladium (II) and ruthenium (III), present as nitrosyl cations $\mathrm{RuNO}^{3+}$ in nitric acid solution, are also extracted by the EXAm solvent at high nitric acid concentration. Both cations are preferentially extracted by DMDOHEMA. For palladium, the formation of $1: 2 \mathrm{Pd}\left(\mathrm{NO}_{3}\right)_{2}(\mathrm{DMDOHEMA})_{2}$ complexes has been demonstrated from distribution ratio measurements by Poirot et al. ${ }^{[39]}$ The addition of HDEHP slightly decreases distribution ratios of $\mathrm{Ru}$ and $\mathrm{Pd}$ cations showing an antagonistic effect of the mixture of both extractants. As was seen for $\mathrm{Zr}$, once extracted in organic phase, $\mathrm{Pd}$ and $\mathrm{Ru}$ are very difficult to strip. HEDTA was used to mask Pd extraction but no masking agent was found efficient enough to prevent $\mathrm{Ru}$ extraction. $\mathrm{Ru}$ is partly back-extracted with Mo using citric acid at lower acidity and with lanthanides and iron using TEDGA and oxalic acid before being completely removed from the solvent in the solvent clean-up step (stripped with carbonates in alkaline media).

\section{Americium selective stripping}

Americium is separated from the remaining elements still extracted in the solvent (light lanthanides La$\mathrm{Nd}, \mathrm{Fe}, \mathrm{Ru}$ ) by selective stripping in the aqueous phase using a mixture of two aqueous complexing agents: an aminopolycarboxylate ligand (HEDTA or DTPA), and a $\mathrm{pH}$ buffer polycarboxylic acid (citric or malonic acid) at $\mathrm{pH} \mathrm{2-3.} \mathrm{Thanks} \mathrm{to} \mathrm{the} \mathrm{presence} \mathrm{of} \mathrm{a} \mathrm{N-bearing} \mathrm{amino-polycarboxylate} \mathrm{ligand}$ (HEDTA or DTPA), americium is selectively complexed in the aqueous phase at low acidity ( $\mathrm{pH} 2-3$ ) while lanthanides and iron preferentially remain extracted by HDEHP in the organic phase.

Based on the knowledge acquired through the developments of DIAMEX-SANEX and GANEX processes, ${ }^{[40,41]}$ the mixture of HEDTA 0.5 mol. $\mathrm{L}^{-1}$ and citric acid $0.5 \mathrm{~mol} . \mathrm{L}^{-1}$ at $\mathrm{pH} 3$, was used as the stripping solution in the EXAm hot test performed in 2010. Ln/Am separation factors higher than 9 can be reached on a quite large $\mathrm{pH}$ range (from 2 to 3.5) which is sufficient to ensure a good decontamination of Am from lanthanides (Figure 9).

The speciation of americium and lanthanides was studied by TRLIFS, ESI-MS and distribution measurements with pentadentate HEDTA and tridentate citric acid (cit) ligands in aqueous solution. $\mathrm{Eu}(\mathrm{HEDTA}), \mathrm{Eu}(\mathrm{cit})$, and $\mathrm{Eu}(\mathrm{cit})_{2}$ complexes were identified by TRLIFS experiments in addition with a fourth species at a longer fluorescence lifetime (around $600 \mu \mathrm{s}$, corresponding to 1 or 2 water molecules remaining in the $\mathrm{Eu}^{3+}$ inner coordination sphere). With support of ESI-MS measurements, this species was attributed to the formation of the ternary 1:1:1 Eu(HEDTA)(cit) complex (Figure 10) ${ }^{[42]}$ as previously observed in similar systems in the literature. ${ }^{[43,44]}$ A ternary complex between trivalent f-elements, HEDTA and malonate was recently found under Advanced TALSPEAK conditions using spectroscopic and solvent extraction methods. ${ }^{[45]}$ Stability constants of the different complexes formed with $\mathrm{Am}$ (III) and $\mathrm{Eu}$ (III) including the mixed complex have been determined by distribution measurements and are reported in Table 2.

\section{Process modelling}

\section{$\mathrm{Am} / \mathrm{Cm}$ separation}

All extraction mechanisms that should be taken into account to describe the extraction of $\mathrm{HNO}_{3}$, TEDGA and Ln or An(III) cations in the EXAm process (at high acidity) are depicted in Figure 8. Extraction of minor actinides and lanthanides by the mixture of HDEHP and DMDOHEMA was first 


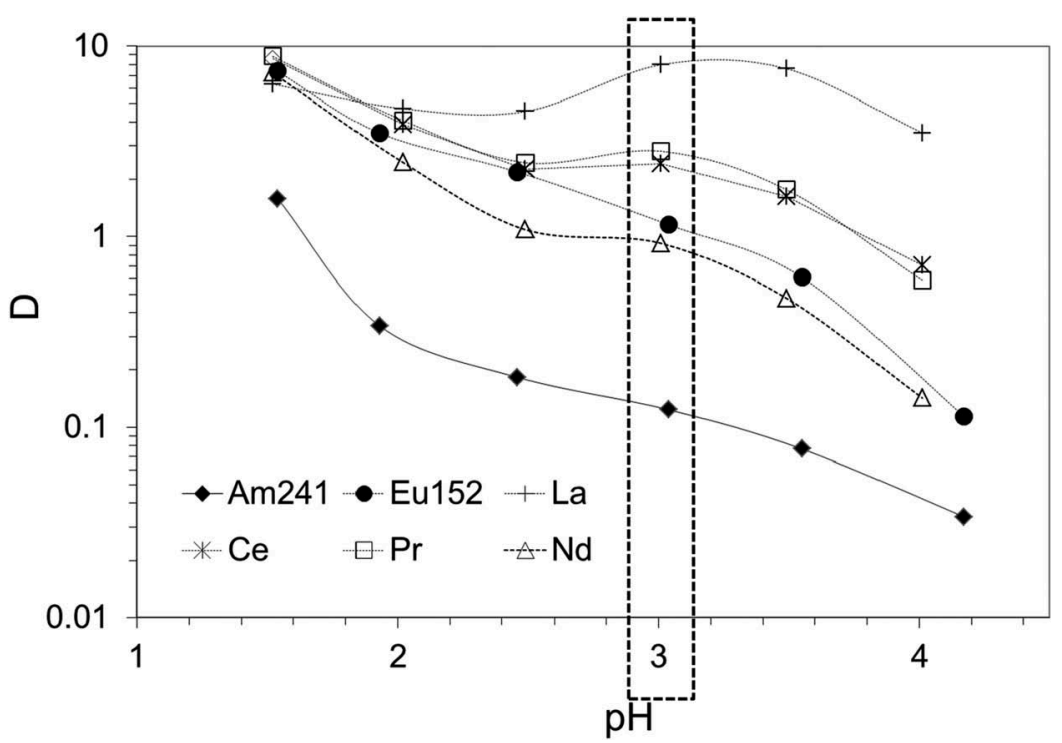

Figure 9. Influence of $\mathrm{pH}$ on distribution ratios of $\mathrm{Am}^{3+}$ and $\mathrm{Ln}^{3+}\left(\mathrm{La}, \mathrm{Ce}, \mathrm{Pr}, \mathrm{Nd},{ }^{152} \mathrm{Eu}\right.$ ) at the stripping step (DMDOHEMA 0.6 mol. $\mathrm{L}^{-1}, \mathrm{HDEHP} 0.3 \mathrm{~mol} . \mathrm{L}^{-1}$ in TPH loaded with traces of $\mathrm{Am}^{3+}$ and $16 \times 10^{-3} \mathrm{~mol}^{-\mathrm{L}^{-1}}$ of $\mathrm{Ln}^{3+}$, HEDTA 0.5 mol.L $\mathrm{L}^{-1}$ citric acid 0.5 mol.L $\mathrm{L}^{-1}$, $\mathrm{pH}$ adjusted with $\mathrm{NaOH}, 25^{\circ} \mathrm{C}$ ).

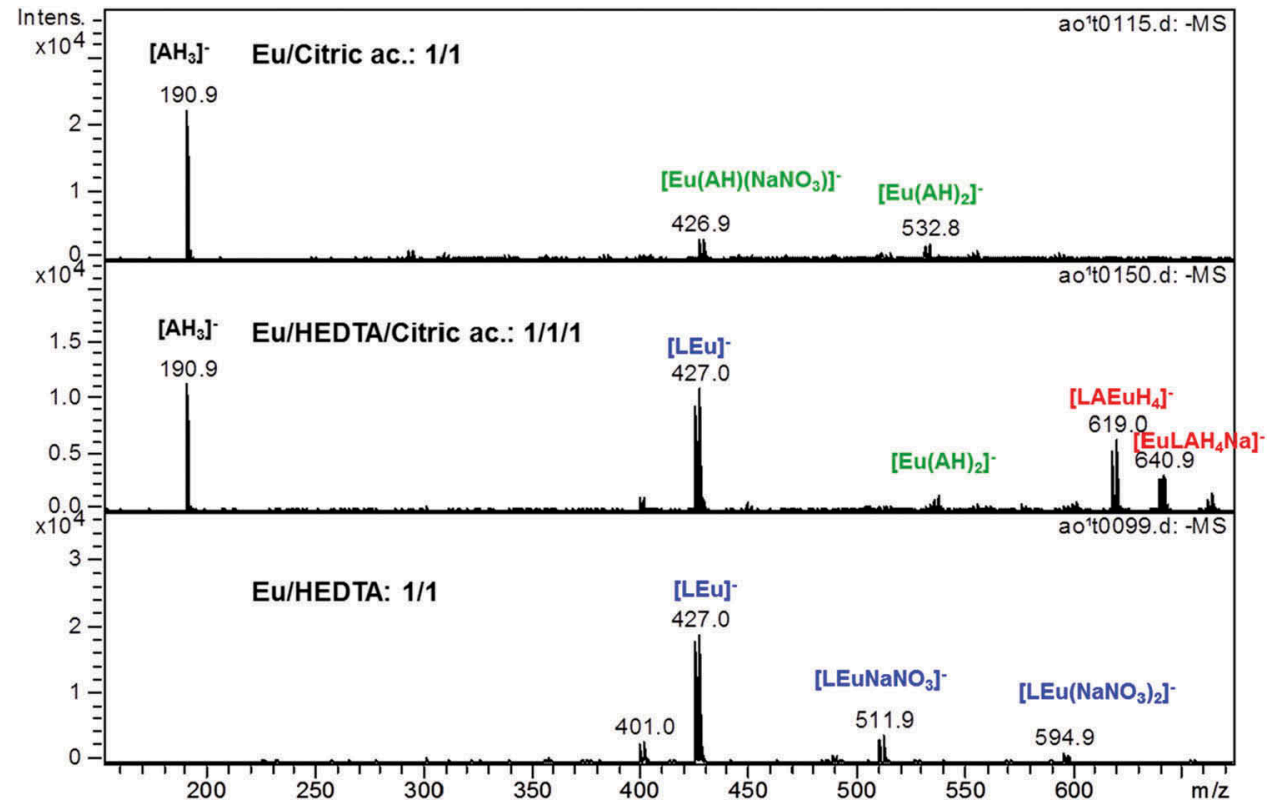

Figure 10. ESI-MS spectrum of Eu/citric acid, Eu/HEDTA, and Eu/HEDTA/citric acid solutions ( $A^{4-}$ : unprotonated citric acid, $\mathrm{L}^{4-}$ unprotonated HEDTA), negative ionization mode.

modelled without TEDGA based on the knowledge acquired through GANEX and DIAMEX-SANEX process development ${ }^{[41,46-49]}$ Except at nitric acid concentration higher than 3 mol. $\mathrm{L}^{-1}$ where the behavior is strictly similar to DMDOHEMA alone, the extraction of $\operatorname{Ln}(\mathrm{III})$ and Am(III) by HDEHP and DMDOHEMA shows a synergistic effect around $0.5-1 \mathrm{~mol} \cdot \mathrm{L}^{-1} \mathrm{HNO}_{3}$ and a slight antagonistic effect 
Table 2. Stability constants $(\log \beta)$ of Am and Eu complexes with HEDTA and citric acid at $0.1 \mathrm{M} \mathrm{NaNO}_{3}, \mathrm{pH}$ $3,25^{\circ} \mathrm{C}$.

\begin{tabular}{lcccc}
\hline Element & $M($ HEDTA $)$ & $M($ cit $)$ & $M(\text { cit })_{2}$ & $M($ HEDTA)(cit) \\
\hline $\mathrm{Am}^{3+}$ & $15.8 \pm 0.2$ & $8.0 \pm 0.1$ & $13.0 \pm 0.2$ & $21.6 \pm 0.6$ \\
$\mathrm{Eu}^{3+}$ & $15.1 \pm 0.1$ & $5.9 \pm 0.1$ & $13.4 \pm 0.5$ & $20.9 \pm 0.5$ \\
\hline
\end{tabular}

at lower acidity. ${ }^{[48]}$ At high acidity, minor actinides and lanthanides extraction was modelled by the following equilibria. The corresponding equilibrium constants are reported in. ${ }^{[35]}$

$$
\begin{gathered}
M^{3+}+3 \mathrm{NO}_{3}^{-}+3 \mathrm{HNO}_{3}+3 \overline{\mathrm{DMDOHEMA}} \rightleftarrows \overline{\mathrm{M}\left(\mathrm{NO}_{3}\right)_{3}\left(\mathrm{HNO}_{3}\right)_{3}(\mathrm{DMDOHEMA})_{3}} \mathrm{~K} 1 \\
M^{3+}+3 \mathrm{NO}_{3}^{-}+3 \overline{\mathrm{HDEHP}}+2 \overline{\mathrm{DMDOHEMA}} \rightleftarrows \overline{M(\mathrm{DEHP})_{3}(\mathrm{DMDOHEMA})_{2}}+3 \mathrm{HNO}_{3} \mathrm{~K} 2
\end{gathered}
$$

Extraction of minor actinides and lanthanides was then modelled in the presence of TEDGA. Distribution of TEDGA was also carefully modelled since it impacts the extraction properties, the Am/Cm selectivity and the solvent loading capacity. TEDGA extraction was first modelled without cations. Experiments performed previously with each extractant separately showed that TEDGA would be extracted by DMDOHEMA after protonation of TEDGA at high acidity. ${ }^{[32]}$ The equilibrium (Equation 3) was considered to correctly fit TEDGA partitioning in organic phase without cations with $\mathrm{K}_{\text {TEDGA }}=2.43 \times 10^{-4} \mathrm{~L}^{12} \cdot \mathrm{mol}^{-12[35]}$

$$
\begin{aligned}
& \text { TEDGA }+5 \mathrm{H}^{+}+4 \mathrm{NO}_{3}^{-}+3 \overline{\mathrm{DMDOHEMA}} \\
& \rightleftarrows \overline{\mathrm{HTEDGA},\left(\mathrm{HNO}_{3}\right)_{4}(\mathrm{DMDOHEMA})_{3}} \text { KTEDGA }
\end{aligned}
$$

TEDGA extraction was then modelled in the presence of lanthanides and minor actinides. Many complexes have been identified with TEDGA both in aqueous and organic phase by different speciation techniques. However, none of these complexes are predominant under the conditions of the EXAm flowsheet and some of them could be neglected in the model. The main complexes and equilibria selected for the modeling are listed in Table 3. In agreement with speciation studies reported before, 1:1, 1:2, and 1:3 M-TEDGA complexes were considered in aqueous phase while the extraction of 1:1 and 1:2 M-TEDGA complexes in the organic phase allowed to reach the best agreement between experimental and calculated distribution data. The whole phenomenological model includes 56 different complexes and their corresponding equilibria constants adjusted by mathematical optimization. Due to the high number of species and equilibria, the validity range of this model was only limited to high nitric acid concentrations expected in the Am/Cm separation step of the process, i.e., between 4 and 5.5 mol.L $\mathrm{L}^{-1} \mathrm{HNO}_{3}$. The implementation of these species in

\begin{tabular}{|c|c|}
\hline Species considered in aqueous phase & \\
\hline $\begin{array}{l}\mathrm{M}(\mathrm{TEDGA}) \\
\mathrm{M}(\mathrm{TEDGA})_{2} \\
\mathrm{M}(\mathrm{TEDGA})_{3} \\
\text { Species considered in organic phase } \\
\mathrm{M}\left(\mathrm{NO}_{3}\right)_{3}\left(\mathrm{HNO}_{3}\right)_{3}(\mathrm{DMDOHEMA})_{3} \\
\mathrm{M}(\mathrm{DEHP})_{3}(\mathrm{DMDOHEMA})_{2} \\
\mathrm{M}\left(\mathrm{NO}_{3}\right)_{3}(\mathrm{TEDGA})(\mathrm{DMDOHEMA}) \\
\mathrm{M}\left(\mathrm{NO}_{3}\right)_{3}(\mathrm{TEDGA})_{2}(\mathrm{DMDOHEMA}) \\
\mathrm{M}\left(\mathrm{NO}_{3}\right)_{2}(\mathrm{DMDOHEMA}) \\
\left.\mathrm{M}\left(\mathrm{NO}_{3}\right)_{2}(\mathrm{HNO})_{3}\right)_{3}(\mathrm{DMDOHEMA}) \\
\mathrm{M}\left(\mathrm{NO}_{3}\right)_{2}(\mathrm{DMDOHEMA})_{2} \\
\mathrm{M}(\mathrm{DEHP})_{2} \\
\mathrm{M}(\mathrm{DEHP})_{3}\end{array}$ & $\begin{array}{c}M=\mathrm{La}, \mathrm{Ce}, \mathrm{Pr}, \mathrm{Nd}, \mathrm{Am} \\
\mathrm{M}=\mathrm{La}, \mathrm{Ce}, \mathrm{Pr}, \mathrm{Sm}, \mathrm{Eu}, \mathrm{Cm} \\
\mathrm{M}=\mathrm{Ce}, \mathrm{Pr}, \mathrm{Nd}, \mathrm{Eu}, \mathrm{Gd}, \mathrm{Zr}, \mathrm{Am} \\
\mathrm{M}=\mathrm{La}, \mathrm{Ce}, \mathrm{Pr}, \mathrm{Nd}, \mathrm{Sm}, \mathrm{Eu}, \mathrm{Gd}, \mathrm{Y}, \mathrm{Am}, \mathrm{Cm} \\
\mathrm{M}=\mathrm{La}, \mathrm{Ce}, \mathrm{Pr}, \mathrm{Nd}, \mathrm{Sm}, \mathrm{Eu}, \mathrm{Gd}, \mathrm{Y}, \mathrm{Am}, \mathrm{Cm} \\
\mathrm{M}=\mathrm{La}, \mathrm{Ce}, \mathrm{Pr}, \mathrm{Nd}, \mathrm{Sm}, \mathrm{Am}, \mathrm{Cm} \\
\mathrm{M}=\mathrm{La}, \mathrm{Ce}, \mathrm{Pr}, \mathrm{Nd}, \mathrm{Am} \\
\mathrm{M}=\mathrm{Pd}, \mathrm{Ru} \\
\mathrm{M}=\mathrm{Pd} \\
\mathrm{M}=\mathrm{Ru} \\
\mathrm{M}=\mathrm{Mo}, \mathrm{Zr} \\
\mathrm{M}=\mathrm{Fe}\end{array}$ \\
\hline
\end{tabular}
the chemical model allows to correctly simulate TEDGA extraction as well as its impact on

Table 3. List of species taken into account for modelling cations extraction in the EXAm process. 
lanthanide extraction by the EXAm solvent for different nitric acid and total lanthanide concentrations (Figure 11). The calculations are consistent with experimental trends and report a decrease of lanthanide and TEDGA extraction with the increase of the atomic number across the lanthanide series. $^{[35]}$

\section{Molybdenum stripping and Am/Ln separation}

These steps occurring at low acidity $\left(\mathrm{HNO}_{3}<0.1 \mathrm{M}\right)$, the extraction of Am, Mo, and Ln by HDEHP and DMDOHEMA must be modelled under these conditions in the absence of complexing agents. In addition to a mixed complex $\mathrm{M}(\mathrm{DMDOHEMA})(\mathrm{DEHP})_{3}$, slightly different from the one considered at higher acidity, the formation of an adduct between HDEHP and DMDOHEMA was assumed to correctly simulate the antagonism effect between both extractants at low acidity. ${ }^{[47,50]}$ HDEHP dimers were not considered in the model as they did not improve the fit. ${ }^{[50]}$ The following extraction equilibria were implemented in the PAREX simulation code $^{[51]}$ to model Am and Ln behavior as well as the $\mathrm{pH}$ change with the EXAm solvent at low acidity.

$$
\begin{gathered}
\mathrm{M}^{3+}+\overline{\overline{\text { DMDOHEMA }}}+3 \overline{\mathrm{HDEHP}} \rightleftarrows \overline{\overline{\mathrm{M}(\text { DMDOHEMA })(\mathrm{DEHP})_{3}}}+3 \mathrm{H}^{+} \\
\overline{\text { DMDOHEMA }}+\overline{\mathrm{HDEHP}} \rightleftarrows \overline{(\text { DMDOHEMA })(\mathrm{DEHP})}
\end{gathered}
$$

According to speciation studies, $\mathrm{Mo}(\mathrm{VI})$ extraction by $\mathrm{HDEHP}$ at $\mathrm{pH}>1$ was modelled by taking into account the three species $\mathrm{MoO}_{2}{ }^{2+}, \mathrm{MoO}_{\overline{5} 3}$ and $\mathrm{MoO}_{4}{ }^{2-}$ in order to reproduce the trend of Mo

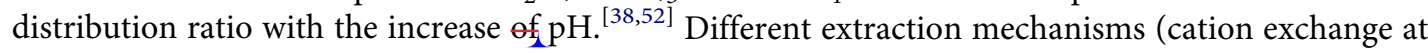
$\mathrm{pH}<2$, solvation at $\mathrm{pH} 2$ to 3 and anion exchange at $\mathrm{pH}>3$ ) were implemented in the PAREX code to simulate Mo extraction. Extraction equilibria are reported in Table 4.

Complexation reactions with HEDTA and citric acid were then added into the model to correctly simulate Am and Ln extraction for conditions of the Am stripping step.
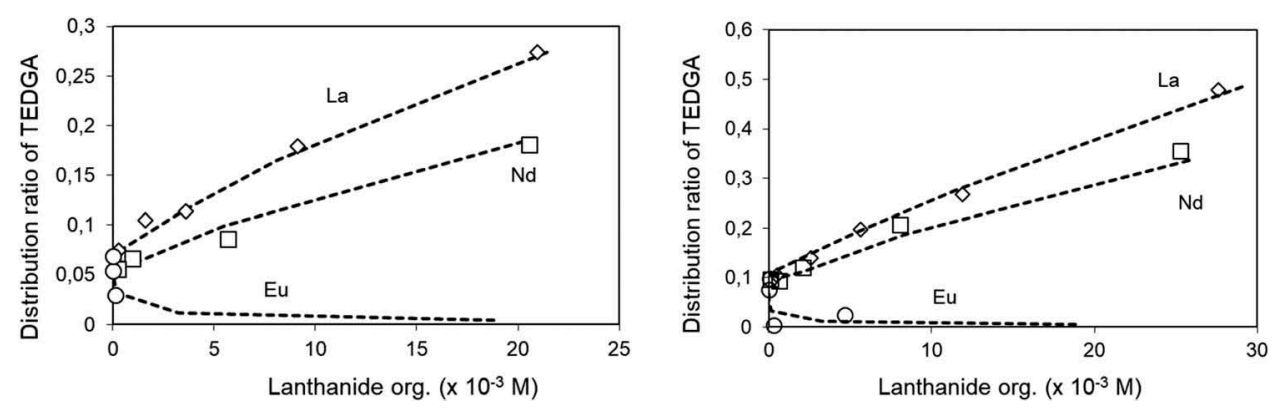

Figure 11. Experimental (symbols) and calculated (dashed line) distribution ratios of lanthanum $(\diamond)$ neodymium ( $\square$ ) and europium $(\bigcirc)$ as a function of the total concentration of lanthanides in the organic phase with TEDGA (left: $\left[\mathrm{HNO}_{3}\right]_{\mathrm{aq}}=4 \mathrm{M}$, $[\mathrm{TEDGA}]_{\text {initial }}=0.05 \mathrm{M}$, right: $\left.\left[\mathrm{HNO}_{3}\right]_{\mathrm{aq}}=5 \mathrm{M},[\mathrm{TEDGA}]_{\text {initial }}=0.05 \mathrm{M}\right)$.

Table 4. Extraction mechanism for Mo depending on the $\mathrm{pH}$ in the EXAm process conditions ${ }^{[38,52]}$.

\begin{tabular}{ll}
\hline \multicolumn{1}{c}{ Extraction mechanism } \\
\hline $\mathrm{pH}<2$ & \multicolumn{1}{c}{ Cation exchangerMoO $\mathrm{Mo}_{2}^{2+}+2 \overline{\mathrm{HDEHP}_{2}} \leftrightarrow \overline{\mathrm{MoO}_{2} D \mathrm{DHP}_{2} \mathrm{HDEHP}_{2}}+2 \mathrm{H}^{+}$} \\
$\mathrm{pH} 2-3$ & Solvating extractant $\mathrm{MoO}_{3}+2 \overline{\mathrm{HDEHP}_{2}} \leftrightarrow \overline{\mathrm{MOO}_{3} \mathrm{HDEHP}_{4}}$ \\
$\mathrm{pH}>3$ & Anion exchanger \\
& $+2 \mathrm{H}_{2} \mathrm{O}$ \\
\hline
\end{tabular}




\section{Flowsheet calculation and hot test demonstration}

\section{Flowsheet design}

After implementation of the different chemical models into the PAREX code, flowsheets were calculated with the goal to recover 99\% of americium from a PUREX HAR with a decontamination factor of Am towards $\mathrm{Cm}$ higher than 500. Inactive, hydrodynamics, and alpha tests were first carried out in laboratory-scale mixer-settlers to assess the accuracy of the process. ${ }^{[53]}$ The separation factor between Am and $\mathrm{Cm}$ being rather low, the compromise between a high Am recovery and a high $\mathrm{Am} / \mathrm{Cm}$ decontamination factor is sharp and requires responsive and efficient process monitoring. Sensitivity analysis was performed with the PAREX code and calculations showed a strong sensitivity on the $\mathrm{DF}_{\mathrm{Am} / \mathrm{Cm}}$ when americium recovery yield exceeds $99 \% .{ }^{[54]}$ The TEDGA concentration was selected as the sensitive parameter to pilot the EXAm process. A startup procedure was defined and a flowsheet correction with a TEDGA flow correction was then proposed based on on-line and analytical measurements during the operation to reach the targeted performances. ${ }^{[54]}$

The complete flowsheet of the EXAm process, including all the steps of the process, was tested in 2010 in the CBP hot cell of ATALANTE facility (Figure 12). Sixty-eight stages of laboratory-scale mixer-settlers were used with 32 stages devoted to Am-Cm separation (16 stages for Am extraction and 16 stages for $\mathrm{Cm}$ scrubbing), 8 stages for Mo stripping, 20 stages dedicated to Am selective stripping (12 for Am stripping and 8 for Ln scrubbing) and 8 stages for Ln \& Fe stripping. The Mo and Am stripping banks of mixer-settlers were heated at $30^{\circ} \mathrm{C}$ and $45^{\circ} \mathrm{C}$ respectively in order to accelerate stripping kinetics. The raffinate used for the EXAm hot test was obtained after the dissolution of used UOX fuels in concentrated nitric acid and further extraction of uranium, plutonium, and neptunium by TBP $30 \%$ diluted in TPH in mixer-settlers. The genuine raffinate was diluted with concentrated nitric acid to adjust the acidity at $10 \mathrm{~mol} . \mathrm{L}^{-1}$. The composition of the feed solution is reported in Table 5.

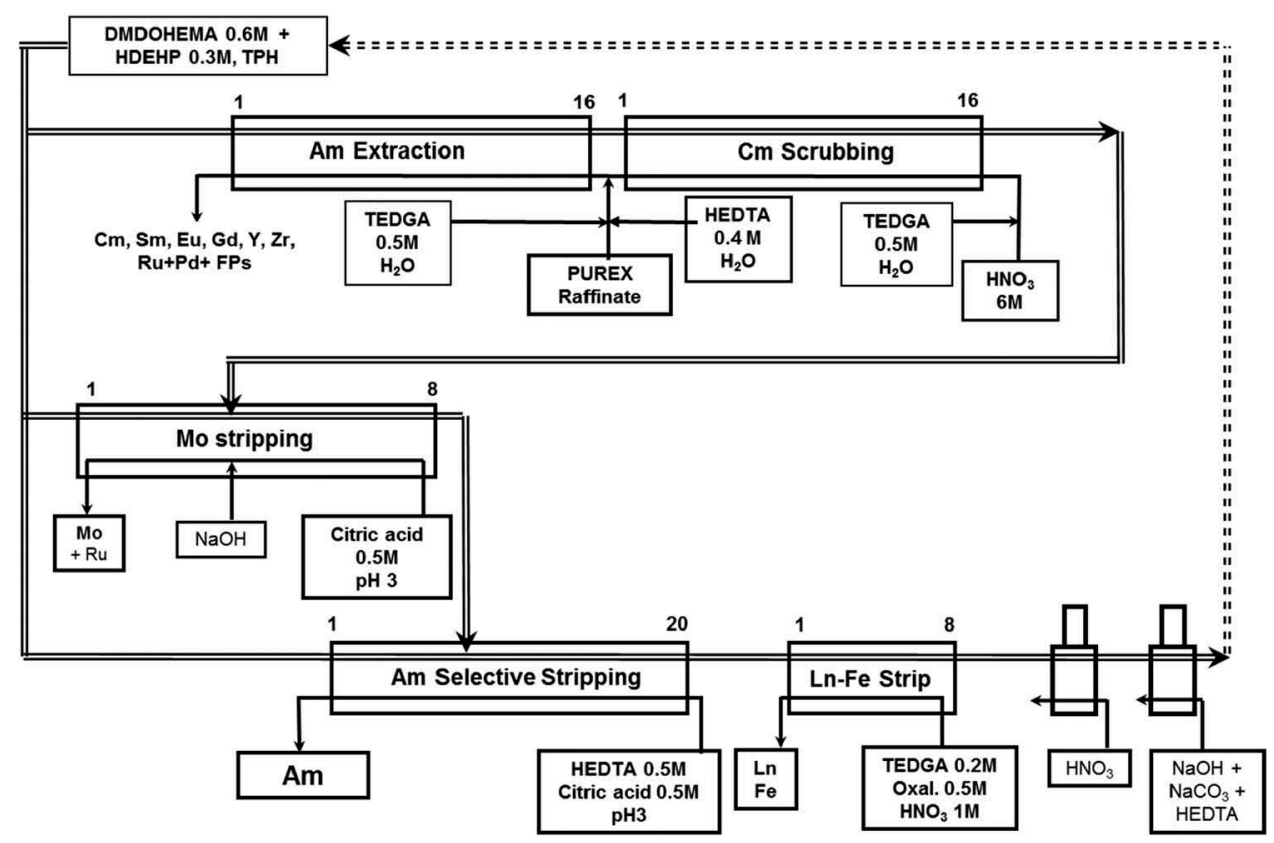

Figure 12. Flowsheet of the EXAm process used for the 2010 hot test ${ }^{[53]}$. 
Table 5. Chemical and radiochemical composition of the EXAm hot test feed solution.

\begin{tabular}{lc}
\hline Feed solution & Concentration \\
\hline $\mathrm{H}^{+}$ & $10 \mathrm{~mol} . \mathrm{L}^{-1}$ \\
$\mathrm{Am}$ & $220 \mathrm{mg} / \mathrm{L}$ \\
$\mathrm{Cm}$ & $21.6 \mathrm{mg} / \mathrm{L}$ \\
$\mathrm{La}$ & $545 \mathrm{mg} / \mathrm{L}$ \\
$\mathrm{Ce}$ & $1000 \mathrm{mg} / \mathrm{L}$ \\
$\mathrm{Pr}$ & $445 \mathrm{mg} / \mathrm{L}$ \\
$\mathrm{Nd}$ & $1650 \mathrm{mg} / \mathrm{L}$ \\
$\mathrm{Sm}$ & $380 \mathrm{mg} / \mathrm{L}$ \\
$\mathrm{Eu}$ & $55 \mathrm{mg} / \mathrm{L}$ \\
$\mathrm{Gd}$ & $73 \mathrm{mg} / \mathrm{L}$ \\
$\mathrm{Sr}$ & $310 \mathrm{mg} / \mathrm{L}$ \\
$\mathrm{Y}$ & $200 \mathrm{mg} / \mathrm{L}$ \\
$\mathrm{Zr}$ & $740 \mathrm{mg} / \mathrm{L}$ \\
$\mathrm{Mo}$ & $975 \mathrm{mg} / \mathrm{L}$ \\
$\mathrm{Ru}$ & $830 \mathrm{mg} / \mathrm{L}$ \\
$\mathrm{Rh}$ & $150 \mathrm{mg} / \mathrm{L}$ \\
$\mathrm{Pd}$ & $550 \mathrm{mg} / \mathrm{L}$ \\
$\mathrm{Fe}$ & $850 \mathrm{mg} / \mathrm{L}$ \\
${ }^{134} \mathrm{Cs}$ & $4.210^{10} \mathrm{~Bq} / \mathrm{L}$ \\
${ }^{137} \mathrm{Cs}$ & $1.2510^{12} \mathrm{~Bq} / \mathrm{L}$ \\
${ }^{154} \mathrm{Eu}$ & $3.8510^{10} \mathrm{~Bq} / \mathrm{L}$ \\
${ }^{155} \mathrm{Eu}$ & $1.2510^{10} \mathrm{~Bq} / \mathrm{L}$ \\
\hline
\end{tabular}

The experiment was run for $54 \mathrm{~h}$ and stopped when the steady-state was reached in the mixersettlers. The analytical results of the hot test samplings indicate that more than $99 \%$ of americium was extracted from the feed solution. At the end, $98.3 \%$ of initial Am were recovered due to small losses detected in the raffinate (1\%) and in the Mo output $(0.7 \%)$. Americium was quantitatively stripped from the EXAm solvent by HEDTA buffered with citric acid at $\mathrm{pH} 3$ while lanthanides and iron remained extracted by HDEHP in the organic phase.

The americium product was very well decontaminated from curium and fission products with decontamination factors of americium towards curium and neodymium of 505 and 340, respectively (Table 6).

Concentration profiles of americium were measured in aqueous and organic phases in all stages of the extraction-scrubbing section at the end of the test. The experimental profiles are compared with the values calculated with the PAREX code in Figure 13. The good agreement observed between experimental and calculated profiles of Am validates the extraction models developed for the EXAm process in this study.

Table 6. Concentrations in the main flux from samples analyzed at the end of the EXAm hot test and corresponding mass balances and decontamination factors.

\begin{tabular}{|c|c|c|c|c|c|c|c|c|}
\hline Element & $\begin{array}{l}\text { Feed } \\
(\mathrm{mg} / \mathrm{L})\end{array}$ & $\begin{array}{l}\text { Raffinate } \\
\text { (mg/L) }\end{array}$ & $\begin{array}{l}\text { Mo output } \\
(\mathrm{mg} / \mathrm{L})\end{array}$ & $\begin{array}{c}\text { Am product } \\
(\mathrm{mg} / \mathrm{L})\end{array}$ & $\begin{array}{l}\text { Ln output } \\
\text { (mg/L) }\end{array}$ & $\begin{array}{l}\text { Used solvent } \\
(\mathrm{mg} / \mathrm{L})\end{array}$ & $\begin{array}{c}\text { Balance (mass } \\
\%)\end{array}$ & DF \\
\hline $\mathrm{Am}$ & 220 & 0.79 & 0.62 & 566 & 0.018 & 0.24 & 105 & \\
\hline $\mathrm{Cm}$ & 21.6 & 10.5 & 0.0002 & 0.11 & 0.0033 & 0.003 & 136 & 505 \\
\hline $\mathrm{Ce}$ & 1000 & $<1$ & $<5$ & $<2.5$ & 960 & & 75 & $>585$ \\
\hline $\mathrm{Nd}$ & 1650 & 3.7 & $<5$ & 12.5 & 2350 & & 113 & 340 \\
\hline Eu & 55 & 21 & 12.5 & $<2.5$ & $<5$ & & 98 & $>61$ \\
\hline $\mathrm{Gd}$ & 73 & 30 & $<2.5$ & $<2.5$ & $<5$ & & 101 & $>85$ \\
\hline Mo & 975 & $<1$ & 420 & $<5$ & $<5$ & & 105 & $>510$ \\
\hline $\mathrm{Zr}$ & 890 & 290 & $<2.5$ & $<5$ & 110 & & 101 & $\begin{array}{c}< \\
458\end{array}$ \\
\hline $\mathrm{Pd}$ & 550 & $<1$ & 190 & 115 & $<5$ & & 95 & 12 \\
\hline $\mathrm{Ru}$ & 830 & 218 & 24 & 15 & 8.1 & 45 & 99 & \\
\hline
\end{tabular}



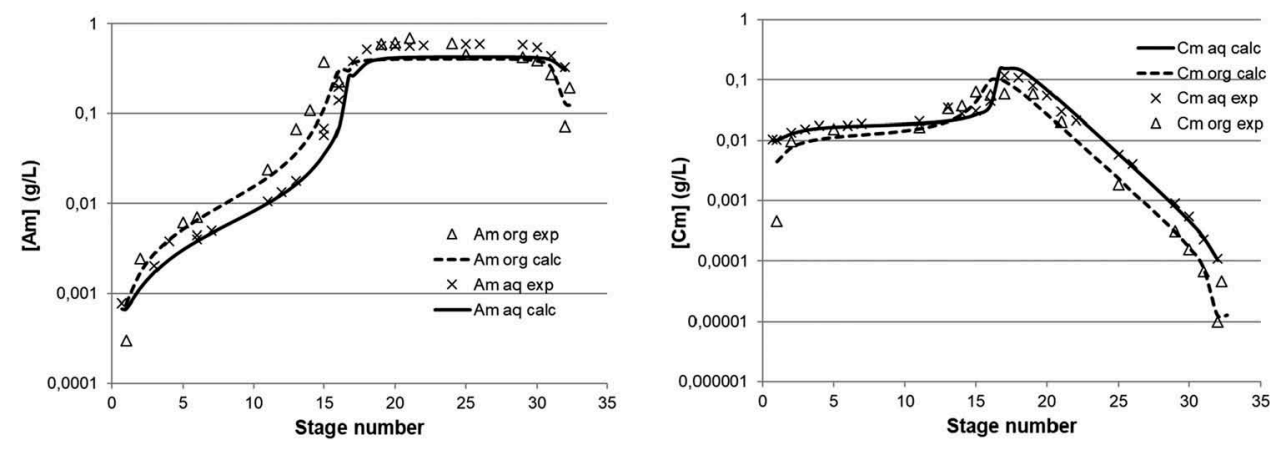

Figure 13. Experimental and calculated americium (left side) and curium (right side) concentration profiles in organic and aqueous phases in the extraction-scrubbing section of the EXAm hot test.

\section{Adaptation of the $m$ process to concentrated raffinates}

From the perspective of a potential future industrial development of the EXAm process, studies were then launched to simplify the flowsheet and assess its robustness. An important R\&D program was conducted in order to improve the process monitoring, define the implementation conditions in continuous contactors such as pulsed columns, improve the solvent clean-up to assess long-term performances of the EXAm solvent, and manage organic reagents introduced in the different steps of the flowsheet (especially downstream steps) to make them compatible with the standard liquid waste treatments of the plant.

One of the objectives of this ambitious program was to develop a dedicated flowsheet for the treatment of concentrated PUREX raffinates. Working on concentrated raffinates would allow a decrease in the feed throughput of the flowsheet and thus reduce the volume of the contactors and the aqueous waste generated, improving the global compactness of a future plant.

\section{Estimation of the maximum concentration factor and optimization of the EXAm flowsheet}

In order to estimate the maximum concentration factor of the PUREX raffinate reachable with the EXAm process, batch experimental data were acquired with increasing concentrations of lanthanides. Concentration factors from 2 to 15 of a classical PUREX UOX3 fuel raffinate (burn-up of 60 $\mathrm{GWd} / \mathrm{t}$ corresponding to approximately $0.02 \mathrm{~mol} . \mathrm{L}^{-1}$ of lanthanides and $0.04 \mathrm{~mol} . \mathrm{L}^{-1}$ of fission products) were tested. As shown in Figure 14, the increase of lanthanide total concentration leads to a sharp decrease of $\mathrm{Am} / \mathrm{Cm}$ selectivity from 2.5 to 1.4. The TEDGA concentration was thus increased to maintain a sufficient $\mathrm{Am} / \mathrm{Cm}$ separation factor but formation of a third phase was observed (for [TEDGA] $>0.3 \mathrm{~mol} . \mathrm{L}^{-1}$ ) with the solvent HDEHP $0.3 \mathrm{~mol} . \mathrm{L}^{-1}$ and DMDOHEMA 0.6 mol. $\mathrm{L}^{-1}$ due to partitioning of TEDGA in organic phase and formation of mixed TEDGADMDOHEMA complexes as previously mentioned in the paper. The HDEHP concentration was increased to prevent third phase formation but it was not possible to go beyond $0.45 \mathrm{~mol} . \mathrm{L}^{-1}$ otherwise Am would be too difficult to strip from the loaded solvent. Under these conditions, the best compromise between a sufficient $\mathrm{Am} / \mathrm{Cm}$ selectivity and a quantitative Am stripping was reached for a concentration factor of 3.5 of a PUREX UOX3 raffinate (corresponding roughly to $70 \mathrm{mmol. \textrm {L } ^ { - 1 }}$ of lanthanides). The concentration factor being limited due to the organic saturation and TEDGA distribution, R\&D was conducted to substitute another water-soluble molecule for TEDGA which could improve Am/Cm selectivity while reducing the ligand partitioning. Several symmetrical and unsymmetrical short-chain DGA compounds were synthesized and tested under the conditions of the EXAm process. ${ }^{[34]}$ Unfortunately, Am/Cm separation factors were systematically lower compared to the value obtained with TEDGA under the same conditions, confirming 


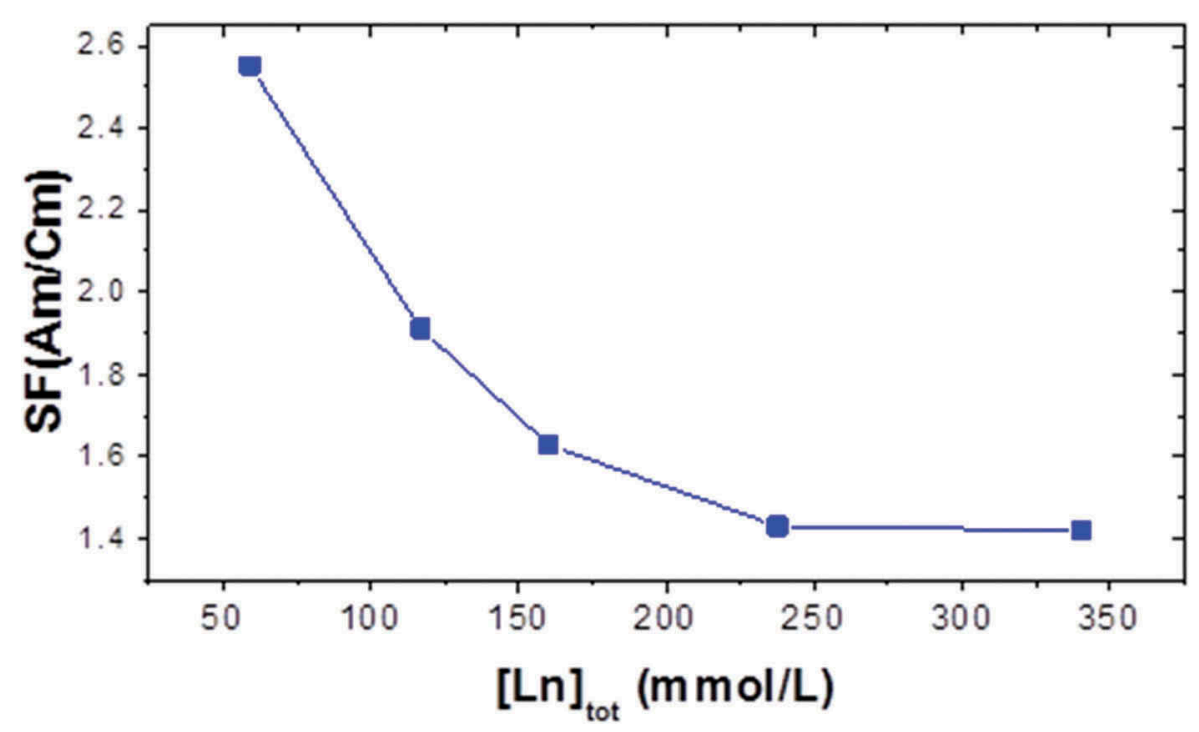

Figure 14. Influence of the total concentration of lanthanides on the $\mathrm{Am} / \mathrm{Cm}$ separation factor. Solvent: HDEHP 0.3 mol.L $\mathrm{L}^{-1}+\mathrm{DMDOHEMA}$ 0.6 mol. $\mathrm{L}^{-1}$ in TPH, pre-equilibrated with $\mathrm{HNO}_{3} 5.5 \mathrm{~mol} . \mathrm{L}^{-1}$ with ${ }^{241} \mathrm{Am}$ and ${ }^{244} \mathrm{Cm}$ radiotracers and [TEDGA] $]_{\text {tot }}=0.15$ mol. $\mathrm{L}^{-1[55]}$.

the optimum of two carbon atoms on each alkyl group for enhancing Am/Cm separation. Besides, new carboxamides developed by Sasaki ${ }^{[56]}$ were also tested but showed a different behavior than TEDGA leading to an inversion of Am/Cm selectivity with $N, N, N^{\prime}, N^{\prime}$-tetraethyl-3,6,9-trioxaundecane diamide (TETOUDA) . ${ }^{[57]}$ TEDGA was thus maintained as selective complexing agent in the new EXAm flowsheet and its concentration was increased to maintain a good Am/Cm separation factor. The amount of TEDGA following Am and light $\mathrm{Ln}$ in the loaded solvent being higher compared to normal EXAm conditions, the impact of higher concentrations of TEDGA was checked on the Mo and Am stripping steps. If no impact was observed on Mo, a sharp decrease in Am distribution ratio was noticed due to TEDGA complexation which could involve a loss of Am in the Mo product. Furthermore, the residual presence of TEDGA at the Am stripping step would decrease Ln distribution ratios and Ln/Am separation factors by lanthanide complexation with TEDGA. Removing TEDGA from the organic phase prior to the Mo stripping step is thus required to avoid any losses of Am. A specific TEDGA scrubbing step was therefore implemented between $\mathrm{Cm}$ scrubbing and Mo stripping steps. Based on PAREX calculations, four stages were added to backextract TEDGA at $\mathrm{HNO}_{3} 4$ mol. $\mathrm{L}^{-1}$ in order to leave less than 0.01 mol.L $\mathrm{L}^{-1}$ of TEDGA in the organic phase and mitigate any impact of TEDGA on the following steps.

The increase of lanthanide, americium, and molybdenum concentrations in the concentrated raffinate also involves a higher quantity of protons exchanged when switching from a solvation extraction mechanism (Equation 1) at high nitric acidity to a cationic exchange mechanism (Equation 4) at lower acidity (in the conditions of the Mo stripping step). These protons must be neutralized to keep a $\mathrm{pH}$ between 2.5 and 3.2 and ensure a good stripping of Mo. Attempts to stabilize the $\mathrm{pH}$ were unsuccessful using glycolic or a mixture of citric and malonic acid. Among the different hydroxy-carboxylic acids tested, citric acid was kept as $\mathrm{pH}$ buffer for the optimized flowsheet as it shows the best compromise between hydrodynamic performances, efficient $\mathrm{pH}$ buffering, and low complexing power towards Am.

Finally, DTPA being a more powerful complexing agent than HEDTA, a lower concentration of DTPA is needed to reach equal stripping performances for increased Am concentrations. On the other hand, malonic acid has the advantage of being more easily destroyed by chemical means after its use in an industrial concentration step, while citric acid is much more robust under these 
conditions and has the additional drawback of degrading to acetic acid. The DTPA-malonic acid solution was then selected instead of the mixture of HEDTA and citric acid in order to handle higher Am concentration and to optimize the oxalic co-conversion of americium into oxide as well as the management of the chemicals in a future potential plant (to mitigate the downstream effects). Hydroxylamine was also preferred to sodium hydroxide to adjust the $\mathrm{pH}$ stripping solution at $\mathrm{pH}$ $2-3$ in order to avoid managing sodium in the aqueous streams. DTPA and malonic concentrations were optimized as well as the $\mathrm{pH}$ and the composition of the stripping solution used for the hot test were DTPA $0.03 \mathrm{~mol} . \mathrm{L}^{-1}$, malonic acid $0.3 \mathrm{~mol} . \mathrm{L}^{-1}$ at $\mathrm{pH}$ 2.6. The possibility to convert americium into $\mathrm{UAmO}_{2}$ compound by oxalic co-precipitation was checked by a dedicated experiment performed on a solution of ${ }^{241} \mathrm{Am}$ with DTPA-malonic acid under representative conditions. After concentration of the Am stripping solution by a factor of 4.5, the co-precipitation of U(IV) and Am(III) was demonstrated with a precipitation yield higher than $99 \%$ in spite of residual quantities of DTPA and malonic acid at $\mathrm{HNO}_{3} 1$ mol.L $\mathrm{L}^{-1}$. A mixed $\left(\mathrm{U}_{0.916}, \mathrm{Am}_{0.084}\right) \mathrm{O}_{2}$ oxide was obtained after thermal treatment at $750^{\circ} \mathrm{C}$ under nitrogen atmosphere, confirming the absence of DTPA, malonic acid, and hydroxylamine impact on the conversion step and therefore the selection of these reagents for the process.

Complexation studies were carried out with DTPA and malonic acid to determine the stoichiometry of the complexes formed with Am and light lanthanides. As already reported many times in the literature, 1:1 complexes were observed between Am, Ln, and DTPA but no ternary 1:1:1 complex was detected between Am, DTPA, and malonic acid in aqueous phase unlike with HEDTA and citric acid in the same conditions. To check the influence of hydroxylamine on americium and lanthanides stripping, $\mathrm{pH}$ dependence distribution experiments were carried out by measuring the distribution ratios of ${ }^{241} \mathrm{Am},{ }^{139} \mathrm{Ce}$, and ${ }^{152} \mathrm{Eu}$ in stripping conditions with DTPA and malonic acid in the $\mathrm{pH}$ range of 1 to 4 adjusted by addition of either sodium hydroxide or hydroxylamine. As reported in Figure 15, a stronger impact of $\mathrm{pH}$ was observed in the case of hydroxylamine with a slope of -2 compared to -1 for sodium hydroxide. The following equilibria were proposed to explain the difference in $\mathrm{pH}$ dependence.

$$
\begin{aligned}
& \overline{\mathrm{Am}(\mathrm{DEHP})_{3}(\mathrm{HDEHP})_{3}}+\mathrm{H}_{4} \mathrm{DTPA} A^{-}+\mathrm{NH}_{3} \mathrm{OH}^{+} \rightleftarrows \mathrm{Am}(\mathrm{DTPA})^{2-}+3 \overline{(\mathrm{HDEHP})}+2 \mathrm{H}^{+} \\
& \quad+\mathrm{NH}_{2} \mathrm{OH}
\end{aligned}
$$

$$
\overline{A m(D E H P)_{3}(H D E H P)_{3}}+H_{4} D T P A^{-} \rightleftarrows A m(D T P A)^{2-}+3 \overline{(H D E H P)}+H^{+}
$$
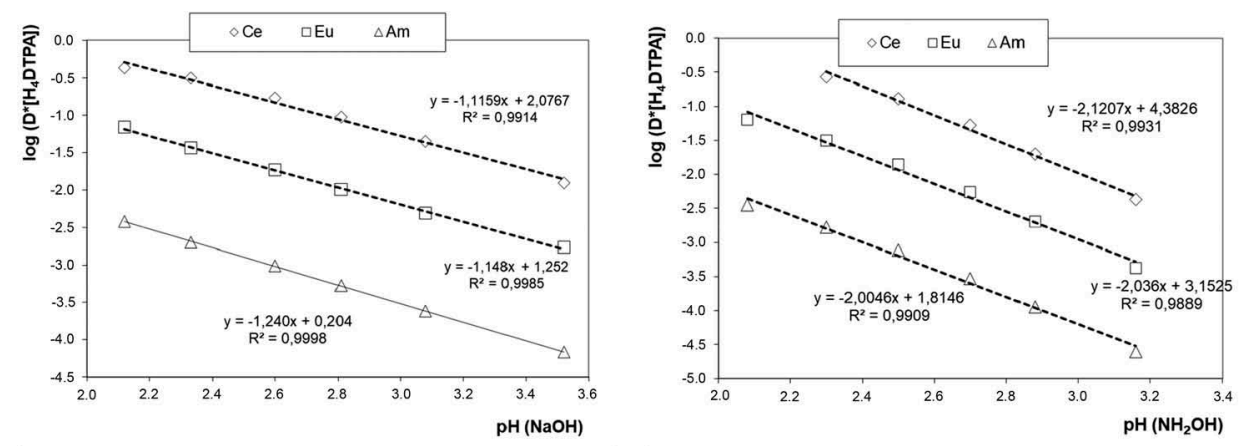

Figure 15. $\mathrm{pH}$ dependencies of $\mathrm{Ce}^{3+}, \mathrm{Eu}^{3+}, \mathrm{Am}^{3+}$ in the conditions of the stripping step of the EXAm solvent (DMDOHEMA 0.6 mol.. ${ }^{-1}$, HDEHP 0.3 mol.L $\mathrm{L}^{-1}$ in TPH, DTPA 0.01 mol.. $\mathrm{L}^{-1}$, malonic acid $0.3 \mathrm{~mol} . \mathrm{L}^{-1}, \mathrm{pH}$ adjusted with sodium hydroxide (left) or hydroxylamine (right), $25^{\circ} \mathrm{C}$. 
One proton would be exchanged in the case of $\mathrm{NaOH}$ confirming the absence of impact of $\mathrm{pH}$ adjustment while two protons would be exchanged in the case of $\mathrm{pH}$ adjusted by $\mathrm{NH}_{2} \mathrm{OH}$. Partial extraction of $\mathrm{NH}_{3} \mathrm{OH}^{+}$by HDEHP (Equation 9) was assumed to explain this behavior and the two following equilibria were implemented in the PAREX simulation code to model Am and Ln stripping under these conditions. Complexation by malonic acid being very weak, it was neglected and not considered in the modelling. ${ }^{[55]}$

$$
\begin{gathered}
M^{3+}+D_{T P A}{ }^{5-} \rightleftarrows M(D T P A)^{2-} \\
\mathrm{NH}_{3} \mathrm{OH}^{+}+\overline{\mathrm{HDEHP}} \rightleftarrows \overline{\left(\mathrm{NH}_{3} \mathrm{OH}\right) \frac{ \pm}{\mathrm{\lambda}}(\mathrm{DEHP})}+\mathrm{H}^{+}
\end{gathered}
$$

The equilibrium constants corresponding to Equations (8) and (9) were fit from batch experimental studies. The extraction constant of $\mathrm{NH}_{3} \mathrm{OH}^{+}$was adjusted at $0.02 \mathrm{~L}^{-\mathrm{mol}^{-1}}$, and the (Am,Ln)-DTPA stability constants are reported in Table $7 .{ }^{[55]}$ Stability constants calculated and implemented in the PAREX code are consistent with literature values obtained by different techniques.

\section{Hot test demonstration of the EXAm process on a concentrated PUREX raffinate}

The PUREX raffinate was obtained after the dissolution of a UOX and LWR MOX mixture of actual spent fuels ( $3 \mathrm{~kg}$ of UOX and $1.6 \mathrm{~kg}$ of MOX) and further extraction of uranium, neptunium, and plutonium by $\mathrm{TBP} 30 \%$ in $\mathrm{TPH}$ in mixer-settlers. The raffinate was then concentrated by hydrodistillation in order to concentrate the different elements while keeping the nitric acid concentration constant in the solution. The acidity was maintained around $8 \mathrm{~mol} . \mathrm{L}^{-1}$ and the concentration factor obtained at the end of the operation corresponds to a concentration factor of 3 of a UOX3 raffinate. The composition of the high active concentrate (HAC) used is reported in Table 8.

The hot test was performed in 2015 in the CBP shielded line of the Atalante facility. The flowsheet used for this test, depicted in Figure 16, was optimized after six preliminary "cold tests" on inactive surrogate solutions and one "alpha test" on a surrogate PUREX raffinate spiked with Am and Cm. ${ }^{\text {[55] }}$ Seventy-two (72) stages of laboratory-scale mixer-settlers were used with 32 stages devoted to Am$\mathrm{Cm}$ separation (16 stages for Am extraction and 16 stages for $\mathrm{Cm}$ scrubbing), 4 stages for TEDGA scrubbing, 12 stages for Mo stripping, 16 stages dedicated to Am selective stripping (12 for Am stripping and 4 for Ln scrubbing) and 8 stages for Ln \& Fe stripping. The used solvent was then recycled after elimination of the residual cations ( $\mathrm{Ru}$ in particular) and the degradation products by a clean-up step including basic and acidic contacts through four stages of centrifugal contactors.

The test was run for more than $90 \mathrm{~h}$ in order to produce sufficiently pure Am for further $\mathrm{UAmO}_{2}$ pellets production. The last $30 \mathrm{~h}$ were devoted to flush the americium present in the different stages of the mixer-settlers in order to maximize Am recovery from the raffinate. At the end of the test, $2.4 \mathrm{~g}$ of americium purified from curium and the fission products were recovered for a further irradiation. The composition of the Am product solution as well as the decontamination factors obtained are reported in Table 9.

Table 7. Stability constants of Am and Ln complexes with DTPA used to model the Am stripping step. ${ }^{[55]}$

\begin{tabular}{lcc}
\hline Element & $\log \beta_{1}$ calc. & $\log \beta_{1} \exp$ (literature) \\
\hline $\mathrm{La}$ & 19.5 & \\
$\mathrm{Pr}$ & 21.1 & \\
$\mathrm{Ce}$ & 20.4 & $20.3^{[58]} 20.4^{[59]}$ \\
$\mathrm{Nd}$ & 21.6 & $22.0^{[58]} 21.7^{[59]}$ \\
$\mathrm{Eu}$ & 22.9 & $22.9^{[58,59]}$ \\
$\mathrm{Am}$ & 23.5 & 2.5 \\
\hline
\end{tabular}


Table 8. Composition of the PUREX HAC after concentration (concentrations are given with an uncertainty of $10 \%)$.

\begin{tabular}{lc}
\hline Elements & Concentration \\
\hline $\mathrm{HNO}_{3}(\mathrm{~mol} / \mathrm{L})$ & 8.2 \\
$\mathrm{Am}_{(\mathrm{mg} / \mathrm{L})}$ & 1095 \\
$\mathrm{Cm}(\mathrm{mg} / \mathrm{L})$ & 323 \\
$\mathrm{La}(\mathrm{mg} / \mathrm{L})$ & 1245 \\
$\mathrm{Ce}(\mathrm{mg} / \mathrm{L})$ & 2169 \\
$\mathrm{Pr}(\mathrm{mg} / \mathrm{L})$ & 956 \\
$\mathrm{Nd}(\mathrm{mg} / \mathrm{L})$ & 3269 \\
$\mathrm{Sm}(\mathrm{mg} / \mathrm{L})$ & 917 \\
$\mathrm{Eu}(\mathrm{mg} / \mathrm{L})$ & 151 \\
$\mathrm{Gd}(\mathrm{mg} / \mathrm{L})$ & 376 \\
$\mathrm{Y}(\mathrm{mg} / \mathrm{L})$ & 129 \\
$\mathrm{Zr}(\mathrm{mg} / \mathrm{L})$ & 900 \\
$\mathrm{Mo}(\mathrm{mg} / \mathrm{L})$ & 1193 \\
$\mathrm{Fe}(\mathrm{mg} / \mathrm{L})$ & 122 \\
$\mathrm{Pd}(\mathrm{mg} / \mathrm{L})$ & 617 \\
$\mathrm{Ru}(\mathrm{mg} / \mathrm{L})$ & 1472 \\
\hline
\end{tabular}

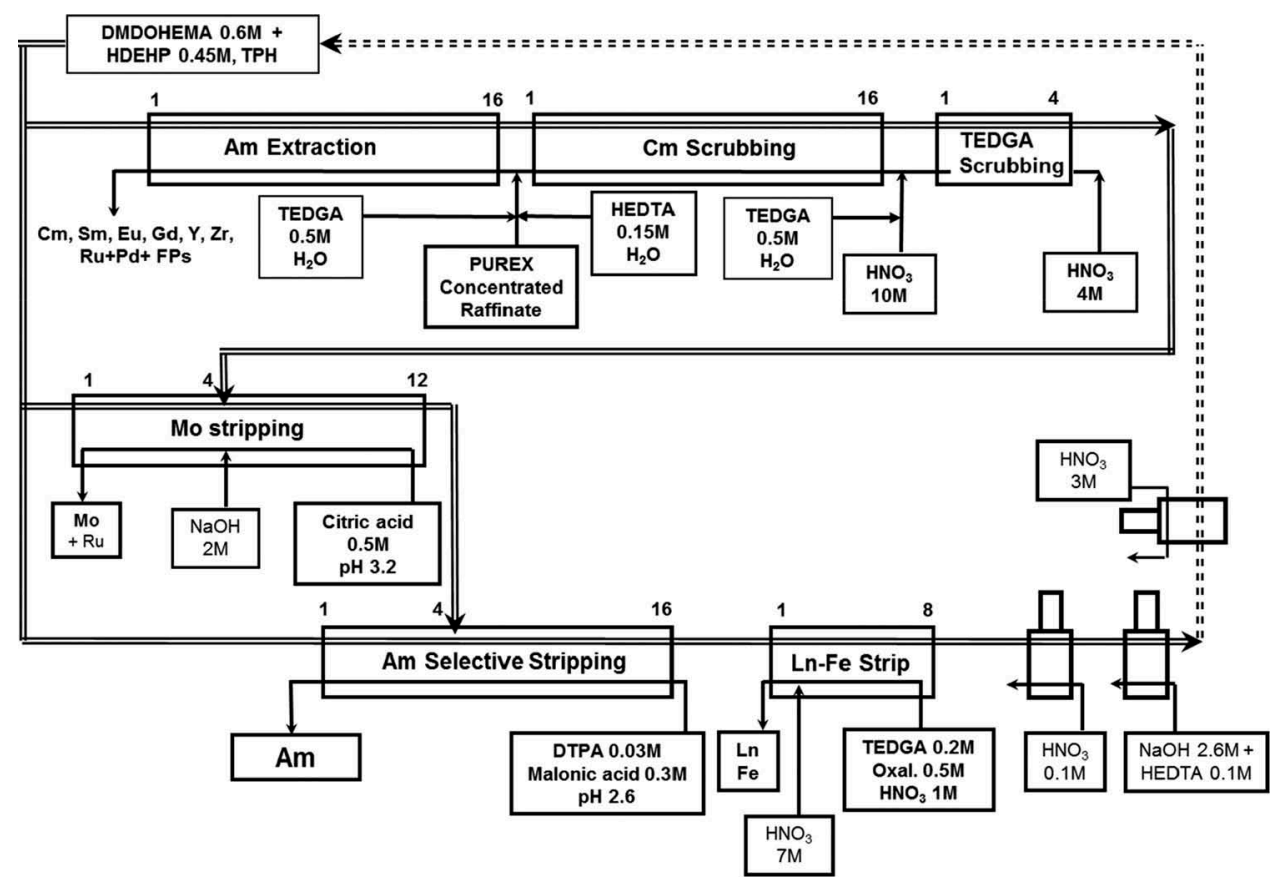

Figure 16. Flowsheet of the EXAm process performed on an actual HAC in 2015.

Table 9. The recovery of americium and the Am/Cm decontamination factor were lower than predicted by modelling calculations. The flowsheet was modified during the test (increase in TEDGA concentration, reduction of flowrates) to increase the decontamination of americium towards curium but it logically involved a decrease in Am extraction. The Am/Cm separation factor observed during the test was lower compared to batch experiments or to the 2010 hot test results. A TEDGA radiolytic degradation due to higher $\mathrm{Am}, \mathrm{Cm}$, and $\mathrm{FP}$ concentrations was first assumed to explain this behavior. HPLC and NMR analysis of the aqueous phase sampled from a stage of the TEDGA scrubbing step showed, however, very low degradation of TEDGA. The lower separation factor was then attributed to an inaccurate modelling of curium extraction in presence of TEDGA with higher 
Table 9. Concentrations of the main elements measured in the Am product collected at the end of the test and estimation of decontamination factors.

\begin{tabular}{lccc}
\hline Element & Concentration $\left(\mathrm{mg} \cdot \mathrm{L}^{-1}\right)$ & $\%$ & $\mathrm{DF}_{\mathrm{Am} / \mathrm{M}}$ \\
\hline $\mathrm{Am}$ & 884 & $\sim 82 \%$ & \\
$\mathrm{Cm}$ & 5.3 & $0.6 \%$ & $\sim 50$ \\
$\mathrm{La}$ & $<0.05$ & $1.8 \%$ & \\
$\mathrm{Ce}$ & 2.1 & & $\sim 200$ \\
$\mathrm{Pr}$ & 1.4 & & \\
$\mathrm{Nd}$ & 13.2 & & \\
$\mathrm{Sm}$ & $<0.05$ & $0.05 \%$ & \\
$\mathrm{Mo}$ & 0.47 & & \\
$\mathrm{Zr}$ & 0.05 & $0.3 \%$ & \\
$\mathrm{Fe}$ & 2.7 & $0.7 \%$ & \\
$\mathrm{Pd}$ & 6.3 & $1.1 \%$ & \\
$\mathrm{Ru}$ & 9.9 & & \\
\hline
\end{tabular}

concentrations of americium and curium. As only extraction of the 1:1 CmTEDGA complex in the organic phase is considered in the model (see Table 3), its extraction constant was adjusted in order to better simulate the $\mathrm{Cm}$ concentration measured in the raffinate during the test. The increase of the 1:1 CmTEDGA stability constant is also consistent with the value recently measured by Klass et al. for Cm-TEDGA complexes by TRLIFS. ${ }^{[33]}$ In the conditions of the Cm scrubbing section, the $\mathrm{Am} / \mathrm{Cm}$ separation factor was estimated at 1.8 with this new model instead of 2.3 previously.

A decontamination factor of 65 consistent with the experimental value $\left(\mathrm{DF}_{\mathrm{Am} / \mathrm{Cm} \text {, exp }} \sim 50\right)$ was calculated while a value of 4500 was considered with the former extraction constant. This modified model was then used to estimate the number of theoretical stages for recovering $98 \%$ of Am with a decontamination factor of 500 towards $\mathrm{Cm}$. It appears that 40 stages of $\mathrm{Cm}$ scrubbing (24 more than in this flowsheet) would have been required to reach these performances. Nevertheless, even if the $\mathrm{DF}_{\mathrm{Am} / \mathrm{Cm}}$ was lower than targeted, the low fraction of $\mathrm{Cm}(0.6 \%)$ detected in the recovered Am solution is still compatible with the irradiation of $\mathrm{UAmO}_{2}$ pellets in a MTR (Material Test Reactor).

As reported in Table 9, americium was also very well decontaminated from the fission products including lanthanides. An average of $1.8 \%$ of lanthanides were found in the Am product, essentially because of a $\mathrm{Nd}$ leak only observed during the first hours of the test whereas the equilibrium was not reached in the mixer-settlers. At the steady state, the decontamination factor of Am towards Nd was higher than 600. The behavior of the other fission products is consistent to expected performances. Molybdenum was quantitatively back-extracted at the Mo stripping step while less than $0.1 \%$ of Am was lost at this step. Palladium was efficiently masked by HEDTA in the Am extraction step while light lanthanides, iron, and ruthenium were quantitatively back-extracted by TEDGA and oxalic acid in the last step of the process.

The Am solution recovered from this test was then concentrated and converted as Am oxide. Approximately $8 \mathrm{~g}$ of $\mathrm{U}_{0.85} \mathrm{Am}_{0.15} \mathrm{O}_{2}$ were obtained after oxalic precipitation and calcination. This powder will be further used to elaborate $\mathrm{UAmO}_{2}$ pellets in order to transmute americium as Ambearing blankets in an experimental fast neutron reactor.

\section{Conclusion}

The development of the EXAm process to recover only americium from PUREX raffinates is based on the knowledge learned during the past 20 years by the CEA teams focused on the development of minor actinides separation processes by diamide-like extractants. The challenge of the EXAm process lies in the selective extraction of just americium directly from a PUREX highly active raffinate at high acidity and in presence of curium and all fission and corrosion products. The core of the process is the extraction step with the main separation of Am from $\mathrm{Cm}$ and heavier lanthanides. The extractant system used for the separation is a mixture of HDEHP and DMDOHEMA diluted in an aliphatic diluent $(\mathrm{TPH})$. The low selectivity towards $\mathrm{Am}\left(\mathrm{SF}_{\mathrm{Am} / \mathrm{Cm}}\right.$ 
$=1.6)$ is improved by the addition into the feed solution of the water-soluble complexing agent TEDGA which enables the process to reach a separation factor of 2.5. Batch distribution experiments supported by speciation studies have highlighted the major role of TEDGA in the process. Distribution of TEDGA into the organic phase was reported and explained by partial coextraction with nitric acid and some cations (light lanthanides and americium in particular) in DMDOHEMA complexes. The change in speciation with the atomic number through the series would explain the differences observed in extraction behavior between light and heavy lanthanides and therefore between Am and $\mathrm{Cm}$. Based on distribution measurements and speciation studies, chemical models were proposed for each step of the process. A flowsheet was calculated with the PAREX code and first tested on a genuine PUREX HAR in 2010. The results were very promising as 98\% of Am was recovered, very well decontaminated towards $\mathrm{Cm}(\mathrm{DF}=500)$ and lanthanides.

An ambitious R\&D program was then launched to assess the performances of the process from the perspective of a future industrial implementation of the EXAm process. The synthesis of the extractants able to decrease the costs of the fabrication, the feasibility of the process implementation in industrial liquid-liquid contactors (pulsed columns, mixers settlers), the process monitoring, the clean-up, and the regeneration of the solvent and the treatment of aqueous wastes have been studied in great detail and did not show any major issues for up-scaling the process. Another objective was to adapt the process to treat concentrated PUREX raffinates in order to improve the compactness of the future workshop/ facility. The flowsheet was thus optimized to handle higher concentrations of minor actinides and fission products. A concentration factor of a PUREX UOX3-type raffinate up to 3.5 could be reached after modifications (increase f $_{\mathbf{L}}$ HDEHP and TEDGA concentrations, addition of a TEDGA scrub). This new flowsheet was tested on a genuine PUREX HAC in laboratory-scale mixer-settlers in 2015 in the framework of an integral experiment. About $82 \%$ of americium was recovered with a decontamination factor of 50 versus curium. These values were lower than expected by calculations. The difference was attributed to an inaccurate modelling of curium complexation by TEGDA potentially explained by a different chemistry occurring at higher concentrations of curium. Americium was nevertheless purified enough from curium and fission products to be transmuted in a fast neutron reactor in the next coming years in order to demonstrate the closing of the americium fuel cycle. Meanwhile, R\&D is also in progress in the frame of European projects to improve and simplify the EXAm process. New alternative processes based on TODGA-octanol mixture in the organic phase and either TPAEN (N,N, $\mathrm{N}^{\prime}, \mathrm{N}^{\prime}$-tetrakis[(6-carboxypyridin-2-yl)methyl] ethylenediamine) ${ }^{[60-65]}$ or $\mathrm{SO}_{3}$-Ph-BTBP $\left(6,6^{\prime}\right.$-bis (5,6-di (3-sulphophenyl)-1,2,4-triazin-3-yl)-2,2'-bipyridine tetrasodium salt) ${ }^{[65-67]}$ as selective Am-stripping agent in aqueous phase have been recently assessed and seem to be promising routes for the separation of americium from PUREX raffinates by solvent extraction.

\section{ORCID}

Manuel Miguirditchian (D) http://orcid.org/0000-0002-7676-757X

Vincent Vanel (D) http://orcid.org/0000-0001-8849-2174

Cécile Marie (D) http://orcid.org/0000-0002-4373-0228

\section{References}

Lanham, W. B.; Runion, T. C. PUREX Process for Plutonium and Uranium Recovery. Oak Ridge National Laboratory report ORNL-479; United States, 1949.

[2] Poinssot, C.; Bourg, S.; Ouvrier, N.; Combernoux, N.; Rostaing, C.; Vargas-Gonzalez, M.; Bruno, J. Assessment of the Environmental Footprint of Nuclear Energy Systems. Comparison between Closed and Open Fuel Cycles. Energy. 2014, 69, 199-211. DOI: 10.1016/j.energy.2014.02.069. Hoorelbeke, J.-M.; Lagrange, M.-H.; Chabert, C. Proceedings of International Conference on Fast Reactors and Related Fuel Cycles (FR13), Paris, France, March 4-7, 2013.

Madic, C.; Blanc, P.; Condamines, N.; Baron, P.; Berthon, L.; Nicol, C.; Lecomte, M.; Philippe, M.; Masson, M.; Hudson, M. Proceedings of RECOD’94, London, UK, April 24-28, 1994. 
[5] Berthon, L.; Morel, J. M.; Zorz, N.; Nicol, C.; Virelizier, H.; Madic, C. Diamex Process for Minor Actinide Partitioning: Hydrolytic and Radiolytic Degradations of Malonamide Extractants. Separ. Sci. Technol. 2001, 36, 709-728. DOI: 10.1081/SS-100103616.

[6] Cuillerdier, C.; Musikas, C.; Hoel, P.; Nigond, L.; Vitart, X. Malonamides as New Extractants for Nuclear Waste Solutions. Separ. Sci. Technol. 1991, 26, 1229-1244. DOI: 10.1080/01496399108050526.

[7] Cuillerdier, C.; Musikas, C.; Nigond, L. Diamides as Actinide Extractants for Various Waste Treatments. Separ. Sci. Technol. 1993, 28, 155-175. DOI: 10.1080/01496399308019484.

[8] Modolo, G.; Vijgen, H.; Serrano-Purroy, D.; Christiansen, B.; Malmbeck, R.; Sorel, C.; Baron, P. DIAMEX Counter-Current Extraction Process for Recovery of Trivalent Actinides from Simulated High Active Concentrate. Separ. Sci. Technol. 2007, 42, 439-452. DOI: 10.1080/01496390601120763.

[9] Nigond, L.; Condamines, N.; Cordier, P. Y.; Livet, J.; Madic, C.; Cuillerdier, C.; Musikas, C.; Hudson, M. J. Recent Advances in the Treatment of Nuclear Wastes by the Use of Diamide and Picolinamide Extractants. Separ. Sci. Technol. 1995, 30, 2075-2099. DOI: 10.1080/01496399508010394.

[10] Nigond, L.; Musikas, C.; Cuillerdier, C. Extraction by N,N,N',N-tetraalkyl-2 Alkylpropane-1,3 Diamides. I. $\mathrm{H}_{2} \mathrm{O}, \mathrm{HNO}_{3}$ and $\mathrm{HClO}_{4}$. Solvent Extr. Ion. Exc. 1994, 12, 261-296. DOI: 10.1080/07366299408918211.

[11] Hill, C.; Berthon, L.; Guillaneux, B.; Dancausse, J. P.; Madic, C. Abstr. Pap. Am. Chem. S. Sanex-BTP Process Development: From Bench to Hot Test Demonstration. 227th National Meeting of the American-Chemical Society, Anaheim, CA, USA, MAR 28-APR 01, 2004, 227.

[12] Kolarik, Z.; Mullich, U.; Gassner, F. Selective extraction of Am(III) over Eu(III) by 2,6-Ditriazolyl- and 2,6-Ditriazinylpyridines1. Solvent. Extr. Ion. Exc. 1999, 17(1), 23-32. DOI: 10.1080/07360299908934598.

[13] Kolarik, Z.; Mullich, U.; Gassner, F. Extraction of Am(lll) and Eu(lll) nitrates by 2-6-DI-(5,6-Dipropyl1,2,4-Triazin-3-YL)Pyridines 1. Solvent. Extr. Ion. Exc.. 1999, 17(5), 1155-1170. DOI: 10.1080/ 07366299908934641.

[14] Miguirditchian, M.; Guillaneux, D.; Guillaumont, D.; Moisy, P.; Madic, C.; Jensen, M. P.; Nash, K. L. Thermodynamic Study of the Complexation of Trivalent Actinide and Lanthanide Cations by ADPTZ, a Tridentate N-Donor Ligand. Inorg. Chem. 2005, 44(5), 1404-1412. DOI: 10.1021/ic0488785.

[15] Adnet, J. M.; Donnet, L.; Chartier, D.; Bros, P.; Faure, N.; Broussard, P. Proceedings of Workshop on LongLived Radionuclide Chemistry in Nuclear Waste Treatment, Villeneuve-lès-Avignon, France, June 18-20, 1997.

[16] Baron, P.; Hérès, X.; Lecomte, M.; Masson, M. Proceedings of Global 2003, New Orleans, USA, November 1620, 2003.

[17] Boubals, N.; Drew, M. G. B.; Hill, C.; Hudson, M. J.; Iveson, P. B.; Madic, C.; Russell, M. L.; Youngs, T. G. A. Americium(iii) and Europium(iii) Solvent Extraction Studies of Amide-substituted Triazine Ligands and Complexes Formed with Ytterbium(iii). J. Chem. Soc. Dalton. 2002, 55-62. DOI:10.1039/b104181a.

[18] Christiansen, B.; Apostolidis, C.; Carlos, R.; Courson, O.; Glatz, J. P.; Malmbeck, R.; Pagliosa, G.; Romer, K.; Serrano-Purroy, D. Advanced Aqueous Reprocessing in P\&T Strategies: Process Demonstrations on Genuine Fuels and Targets. Radiochim. Acta. 2004, 92, 475-480. DOI: 10.1524/ract.92.8.475.39283.

[19] Courson, O.; Lebrun, M.; Malmbeck, R.; Pagliosa, G.; Romer, K.; Satmark, B.; Glatz, J. P. Partitioning of Minor Actinides from HLLW Using the DIAMEX process.Part 1 - Demonstration of Extraction Performances and Hydraulic Behaviour of the Solvent in a Continuous Process. Radiochim. Acta. 2000, 88, 857-863. DOI: 10.1524/ract.2000.88.12.857.

[20] Drew, M. G. B.; Iveson, P. B.; Hudson, M. J.; Liljenzin, J. O.; Spjuth, L.; Cordier, P. V.; Enarsson, A.; Hill, C.; Madic, C. Separation of americium(III) from europium(III) with Tridentate Heterocyclic Nitrogen Ligands and Crystallographic Studies of Complexes Formed by 2,2' $\square 6^{\prime}, 2^{\prime \prime}$-terpyridine with the Lanthanides. J. Chem. Soc. Dalton. 2000, 821-830. DOI:10.1039/a907077j.

[21]\Madic, C.; Hudson, M.; Liljenzin, J. O.; Glatz, J. P.; Nannicini, R.; Facchini, A.; Kolarik, Z. R. O. New Partitioning Techniques for Minor Actinides: NEWPART. EUR 19149 EN European Commission, Luxembourg, 2000.

[22] Madic, C.; Testard, F.; Hudson, M.; Liljenzin, J.-O.; Christiansen, B.; Ferrando, M.; Facchini, A.; Geist, A.; Modolo, G.; De Mendoza, A. G.-E. J. New Solvent Extraction Processes for Minor Actinides PARTNEW Program, Report CEA-R-6066; France, 2004.

[23] Serrano-Purroy, D.; Baron, P.; Christiansen, B.; Malmbeck, R.; Sorel, C.; Glatz, J. P. Recovery of Minor Actinides from HLLW Using the DIAMEX Process. Radiochim. Acta. 2005, 93, 351-355.

[24] Geist, A.; Adnet, J. M.; Bourg, S.; Ekberg, C.; Galan, H.; Guilbaud, P.; Miguirditchian, M.; Modolo, G.; Rhodes, C.; Taylor, R. An Overview of Solvent Extraction Processes Developed in Europe for Advanced Nuclear Fuel Recycling, Part 1 -Heterogeneous Recycling. Separ. Sci. Technol. 2020, Submitted.

[25] Modolo, G.; Geist, A.; Miguirditchian, M. Reprocessing and Recycling of Spent Nuclear Fuel; Taylor, R., Ed.; Woodhead Publishing, Elsevier: Cambridge, 2015.

[26] Baron, P.; Masson, M.; Rostaing, C.; Boullis, B. Proceedings of Global 2007: Advanced Nuclear Fuel Cycles, Boise, Idaho, United-States, 2007.

[27] Warin, D. Status of the French Research Program on Partitioning and Transmutation. J. Nucl. Sci. Technol. 2007, 44(3), 410-414. DOI:10.1080/18811248.2007.9711302. 
[28] Sasaki, Y.; Sugo, Y.; Kitatsuji, Y.; Kirishima, A.; Kimura, T.; Choppin, G. R. Complexation and Back Extraction of Various Metals by Water-soluble Diglycolamide. Anal. Sci. 2007, 23, 727-731. DOI: 10.2116/analsci.23.727.

[29] Ramond, L.; Coste, P.; Picart, S.; Gauthe, A.; Bataillea, M. Fabrication of (U,am)o2 Pellet with Controlled Porosity from Oxide Microspheres. J. Nucl. Mater. 2017, 492, 97-101. DOI: 10.1016/j.jnucmat.2017.05.005.

Valentin, B.; Lainet, M.; Pelletier, M.; Chauvin, N.; Gallais-During, A. Proceedings of 15th IEMPT NEA Information Exchange Meeting on Actinide and Fission Product Partitioning and Transmutation, Manchester, UK, September-October 30th-3rd, 2018.

(D) Hérès, X.; Baron, P. Increase in the Separation Factor between Americium and Curium And/or between Lanthanides in a Liquid-liquid Extraction Process, Patent WO 2011012579, 2009.

[32] Chapron, S.; Marie, C.; Arrachart, G.; Miguirditchian, M.; Pellet-Rostaing, S. New Insight into the Americium/ Curium Separation by Solvent Extraction Using Diglycolamides. Solvent Extr. Ion. Exc. 2015, 33, $236-248$. DOI:10.1080/07366299.2014.1000792.

[33] Klass, L.; Wilden, A.; Kreft, F.; Wagner, C.; Geist, A.; Panak, P. J.; Herdzik-Koniecko, I.; Narbutt, J.; Modolo, G. Evaluation of the Hydrophilic Complexant N,N,N',N'-tetraethyldiglycolamide (TEDGA) and its Methyl-substituted Analogues in the Selective Am(III) Separation. Solvent Extr. Ion. Exc. 2019, 37, 297-312. DOI:10.1080/ 07366299.2019.1651039.

[34] Chapron, S.; Marie, C.; Pacary, V.; Duchesne, M. T.; Arrachart, G.; Pellet-Rostaing, S.; Miguirditchian, M. Separation of Americium by Liquid-Liquid Extraction Using Diglycolamides Water-Soluble Complexing Agents. Procedia Chem. 2016, 21, 133-139. DOI: 10.1016/j.proche.2016.10.019.

[35] Pacary, V.; Burdet, F.; Duchesne, M. T. Experimental and Modeling of Extraction of Lanthanides in System HNO3-TEDGA-\{DMDOHEMA-HDEHP\}. Procedia Chem. 2012, 7, 328-333. DOI: 10.1016/j. proche.2012.10.052.

[36] Charbonnel, M. C.; Berthon, C.; Berthon, L.; Boubals, N.; Burdet, F.; Duchesne, M. T.; Guilbaud, P.; Mabille, N.; Petit, S.; Zorz, N. Complexation of $\operatorname{Ln}(\mathrm{III})$ and Am(III) with the Hydrosoluble TEDGA: Speciation and Thermodynamics Studies. Procedia Chem. 2012, 7, 20-26. DOI: 10.1016/j.proche.2012.10.005.

[37] Tkac, P.; Paulenova, A. Speciation of Molybdenum (VI) in Aqueous and Organic Phases of Selected Extraction Systems. Separ. Sci. Technol. 2008, 43, 2641-2657. DOI: 10.1080/01496390802122261.

[38] Marie, C.; Vanel, V.; Watanabe, S.; Duchesne, M. T.; Zorz, N.; Berthon, L. Behavior of Molybdenum (VI) in \{dmdohema-hdehp/nitric Acid\} Liquid-Liquid Extraction Systems. Solvent Extr. Ion. Exc. 2016, 34, 407-421. DOI:10.1080/07366299.2016.1208029.

[39] Poirot, R.; Bourgeois, D.; Meyer, D. Palladium Extraction by a Malonamide Derivative (DMDOHEMA) from Nitrate Media: Extraction Behavior and Third Phase Characterization. Solvent Extr. Ion. Exc.. 2014, 32, 529-542. DOI:10.1080/07366299.2014.908587.

) Miguirditchian, M. Abstracts of Papers of the American Chemical Society; 239, 2010.

P) Miguirditchian, M.; Sorel, C.; Roussel, H.; Chareyre, L.; Baron, P.; Espinoux, D.; Calor, J. N.; Viallesoubranne, C.; Lorrain, B.; Masson, M. Proceedings of Internat. Conf. GLOBAL 2009 (The Nuclear Fuel Cycle: Sustainable Options \& Industrial Perspectives), France, September 6-11, 2009.

(4) Miguirditchian, M.; Pecheur, O.; Berthon, L.; Couston, L. Proceedings of ISEC 2011, Santiago, Chile, October, 2011.

[43] Thakur, P.; Pathak, P. N.; Gedris, T.; Choppin, G. R. Complexation of Eu(III), Am(III) and Cm(III) with Dicarboxylates: Thermodynamics and Structural Aspects of the Binary and Ternary Complexes. J. Solution Chem. 2009, 38(3), 265-287. DOI: 10.1007/s10953-009-9373-8.

[44] Choppin, G. R.; Thakur, P.; Mathur, J. N. Thermodynamics and the Structure of Binary and Ternary Complexation of $\mathrm{Am}^{3+} \mathrm{Cm}^{3+}$ and $\mathrm{Eu}^{3+}$ with DTPA and DTPA+IDA. C. R. Chim. 2007, 10(10-11), 916-928. DOI: 10.1016/j.crci.2007.03.018.

[45] Lapka, J. L.; Wahu, S.; Sinkov, S.; Nash, K. L. Ternary Complex Formation and Extraction Modeling in Malonate-Buffered Trivalent Actinide-Lanthanide Separations. Inorg. Chem. 2019, 58(11), 7554-7563. DOI: 10.1021/acs.inorgchem.9b00808.

[46] Gannaz, B.; Chiarizia, R.; Antonio, M. R.; Hill, C.; Cote, G. Extraction of Lanthanides(III) and Am(III) by Mixtures of Malonamide and Dialkylphosphoric Acid. Solvent Extr. Ion. Exc. 2007, 25, 313-337. DOI:10.1080/ 07366290701285512.

[47] Muller, J. M.; Berthon, C.; Couston, L.; Guillaumont, D.; Ellis, R. J.; Zorz, N.; Simonin, J. P.; Berthon, L. Understanding the Synergistic Effect on lanthanides(III) Solvent Extraction by Systems Combining a Malonamide and a Dialkyl Phosphoric Acid. Hydrometallurgy. 2017, 169, 542-551. DOI: 10.1016/j. hydromet.2017.02.012.

[48] Muller, J. M.; Berthon, C.; Couston, L.; Zorz, N.; Simonin, J. P.; Berthon, L. Extraction of Lanthanides(III) by a Mixture of a Malonamide and a Dialkyl Phosphoric Acid. Solvent Extr. Ion. Exc.. 2016, 34(2), 141-160. DOI: 10.1080/07366299.2015.1135030.

[49] Muller, J. M.; Berthon, L.; Berthon, C.; Couston, L.; Zorz, N.; Simonin, J. P. Characterization of Americium(III) and Lanthanide(III) Complexes in Mixed Solvent Extraction Systems Containing a Malonamide and a Dialkylphosphoric Acid. Abstr. Pap. Am. Chem. S. 2013, 245. 
[50] Vanel, V.; Berthon, L.; Muller, J.; Miguirditchian, M.; Burdet, F. Modelling of Americium Stripping in the EXAm Process. Procedia Chem. 2012, 7, 404-410. DOI: 10.1016/j.proche.2012.10.063.

(D) Sorel, C.; Montuir, M.; Balaguer, C.; Baron, P.; Dinh, B.; Hérès, X.; Pacary, V.; Roussel, H. Proceedings of ISEC 2011, Santiago, Chile, October, 2011.

) Vanel, V.; Marie, C.; Duchesne, M. T.; Hérès, X.; Pacary, V.; Berthon, L.; Rudloff, D.; Bertrand, M.; Watanabe, S., Proceedings of International Solvent Extraction Conference (ISEC), 2014, Wurtzburg, Germany.

[53] Bollesteros, M. J.; Calor, J. N.; Costenoble, S.; Montuir, M.; Pacary, V.; Sorel, C.; Burdet, F.; Espinoux, D.; Heres, X.; Eysseric, C. Implementation of Americium Separation from a PUREX Raffinate. Procedia Chem. 2012, 7, 178-183. DOI: 10.1016/j.proche.2012.10.030.

[54] Montuir, M.; Pacary, V.; Sorel, C.; Baron, P.; Bollesteros, M. J.; Costenoble, S.; Espinoux, D.; Heres, X.; Rostaing, C. Sensitivity of Americium and Curium Splitting Flowsheet and Running Procedure. Procedia Chem. 2012, 7, 275-281. DOI: 10.1016/j.proche.2012.10.044.

[55] Vanel, V.; Bollesteros, M. J.; Marie, C.; Montuir, M.; Pacary, V.; Antegnard, F.; Costenoble, S.; Boyer-Deslys, V. Consolidation of the EXAm Process: Towards the Reprocessing of a Concentrated PUREX Raffinate. Procedia Chem. 2016, 21, 190-197. DOI: 10.1016/j.proche.2016.10.027.

[56] Sasaki, Y.; Kitatsuji, Y.; Tsubata, Y.; Sugo, Y.; Morita, Y. Separation of Am, Cm and Lanthanides by Solvent Extraction with Hydrophilic and Lipophilic Organic Ligands. Solvent Extr. Res. Dev.-Jpn. 2011, 18, 93-101. DOI: $10.15261 /$ serdj.18.93.

(D) Chapron, S. PhD Thesis; Université de Montpellier II, 2014.

Sillen, L. G.; Martell, A. E.; Bjerrum, J.; Schwarzenbach, G. K. Stability Constants of Metal-Ion Complexes; Chemical Society: London, 1964.

[59] Martell, A. E.; Smith, R. M. Critical Stability Constants; New York, London: Plenum Press, (1974-1989), 1989.

[60] Boubals, N.; Wagner, C.; Dumas, T.; Chaneac, L.; Manie, G.; Kaufholz, P.; Marie, C.; Panak, P. J.; Modolo, G.; Geist, A.; et al. Complexation of Actinide(III) and Lanthanide(III) with H4TPAEN for a Separation of Americium from Curium and Lanthanides. Inorg. Chem. 2017, 56(14), 7861-7869. DOI: 10.1021/acs. inorgchem.7b00603.

[61] Marie, C.; Kaufholz, P.; Vanel, V.; Duchesne, M. T.; Russello, E.; Faroldi, F.; Baldini, L.; Casnati, A.; Wilden, A.; Modolo, G.; et al. Development of a Selective Americium Separation Process Using H 4 TPAEN as Water-Soluble Stripping Agent. Solvent Extr. Ion. Exc.. 2019, 37(5), 313-327. DOI:10.1080/ 07366299.2019.1643569.

[62] Vanel, V.; Marie, C.; Kaufholz, P.; Montuir, M.; Boubals, N.; Wilden, A.; Modolo, G.; Geist, A.; Sorel, C. Modeling and Flowsheet Design of an Am Separation Process Using TODGA and H4TPAEN. Procedia Chem. 2016, 21, 223-230. DOI: 10.1016/j.proche.2016.10.032.

[63] Marie, C.; Pacary, V.; Charbonnel, M. C.; Miguirditchian, M. Séparation de l'américium: développement d'un nouveau procédé d'extraction liquide-liquide. L'Actualité Chimique. 2016, 408-409, 109-111.

(D) Marie, C.; Duchesne, M. T.; Russello, E.; Kaufholz, P.; Wilden, A.; Modolo, G.; Casnati, A.; Miguirditchian, M., Proceedings of GLOBAL 2015 2015, Paris, France,

Modolo, G.; Wilden, A.; Kaufholz, P.; Marie, C.; Vanel, V.; Miguirditchian, M.; Bourg, S.; Casnati, A.; Geist, A., Proceedings of GLOBAL 2019, 2019, Seattle, USA,

[66] Herdzik-Koniecko, I.; Wagner, C.; Trumm, M.; Mullich, U.; Schimmelpfennig, B.; Narbutt, J.; Geist, A.; Panak, P. J. Do An(Iii) and Ln(Iii) Ions Form Heteroleptic Complexes with Diglycolamide and Hydrophilic BT(B)P Ligands in Solvent Extraction Systems? A Spectroscopic and DFT Study. New J. Chem. 2019, 43, 6314-6322. DOI: 10.1039/C9NJ00651F.

[67] Wagner, C.; Mullich, U.; Geist, A.; Panak, P. J. Selective Extraction of Am(III) from PUREX Raffinate: The AmSel System. Solvent Extr. Ion. Exc. 2016, 34, 103-113. DOI:10.1080/07366299.2015.1129192. 